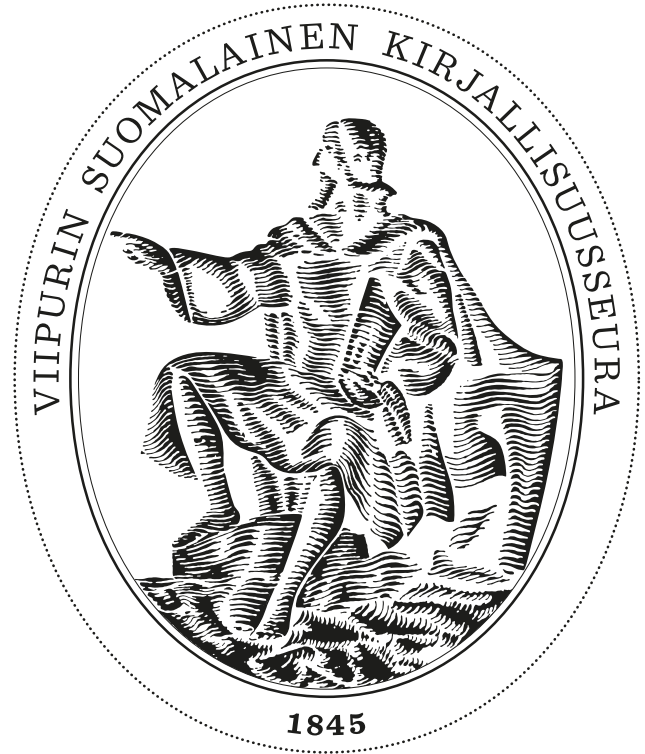

VIIPURIN SUOMALAISEN

KIRJALLISUUSSEURAN

TOIMITTEITA

(18)

Muuttuvien tulkintojen Viipuri 
Kansikuva: Osa Severin Falkmanin vuonna 1886 tekemästä öljymaalauksesta Kaarle Knuutinpoika Bonde lähdössä Viipurin linnasta Tukholmaan kuninkaanvaaliin 1448. Karl Knutson Bonde på väg från Viborgs slott till kungavalet i Stockholm 1448.

Kansallisgalleria/Kirsi Halkola. Ateneumin taidemuseo.

Viipurin Suomalaisen Kirjallisuusseuran Toimitteita osa 18 Muuttuvien tulkintojen Viipuri

Toimittaneet:

Anu Koskivirta (osan päätoimittaja),

Pentti Paavolainen (sarjan päätoimittaja),

Sanna Supponen (sarjan toimitussihteeri)

Kuvatoimitus:

Risto Marjomaa

Graafinen suunnittelu \& taitto:

Eemeli Nieminen, www.eemelinieminen.fi

ISBN: 978-952-67216-3-7 (Toimite 18, PDF)

ISSN: 1236-4304 (Sarja)

Painettu: 2016, Juvenes Print

Painosmäärä: 200 kpl

2. korjattu painos.

Julkaisija: Viipurin Suomalainen Kirjallisuusseura, Helsinki 


\section{Pastori-kirjailija K. H. J. Ignatius (1809-1856): Viipurin fennomanian tuntematon keskushenkilö}

Viipuri oli 1840-luvulla yksi varhaisen fennomanian keskuksista.' Kaupungissa työskenteli tuolloin lehtimiehiä, opettajia, konttoristeja ja virkamiehiä, jotka jakoivat yhteisen tavoitteen: kansankielen aseman parantamisen. Tulevaisuudessa suomi toivottiin saatavan koulu- ja virkakieleksi, ja asiaa edistettiin muun ohella julkaisemalla suomenkielistä sanomalehteä ja valistavaa kansankirjallisuutta. ${ }^{2}$

Suomen historian yleisesityksissä paikallisten valistuksellisten fennomaanien toimintaa käsitellään vain niukasti. Tavallisesti mainitaan Jaakko Juteini varhaisena suomenkielisenä valistuskirjailijana ja lehtimies Pietari Hannikainen modernin sanomalehdistön varhaisena tienraivaajana. Alueellisissa ja kulttuurihistoriallisissa tutkimuksissa on pidetty tärkeänä myös Viipurin Suomalaisen Kirjallisuusseuran (jatkossa VSKS) perustamista vuonna 1845, ja samalla huomiota on kiinnitetty sen työalojen Suomalaisen Kirjallisuuden Seuraa maanläheisempään profiiliin. ${ }^{3}$ Aihetta käsitelleet erikoistutkimukset ovat lisäksi vakiinnuttaneet käsityksen siitä, että Viipurin valistuneiden säätyläisten työskentelyä suomen kielen hyväksi leimasi voimakas yhteiskuntakriittisyys, jota taustoittivat maaseudun sosiaaliset olot, ennen muuta päivänpolttava kysymys vuokraviljelijöiksi vajonneiden lahjoitusmaatalonpoikien asemasta. Tällaisen näkemyksen toi seudun historiakuvan osaksi viimeistään Jouko Teperin tutkimus Vanhan Suomen suomalaisuusliikkeestä (1965). Käsitystä ovat tosin sittemmin haastaneet esimerkiksi Yrjö Kaukiaisen ja Jyrki Paaskosken tutkimukset. ${ }^{4}$

Tämä artikkeli selvittää, kuinka kestävällä pohjalla perinteinen kuva Viipurin varhaisesta suomalaisuusliikkeestä on, mikäli Viipurin fennomanian organisoitumista ja varhaisia toimintamuotoja tarkastellaan ainoastaan yhden henkilön, pastori Karl Henrik Jakob Ignatiuksen (1809-1856) tavoitteiden ja elämänuran näkökulmasta. Ignatius oli paikallisen seuratoiminnan keskeisin organisaattori: pappi, lehtimies, opettaja ja valistuskirjailija. Hänen monialainen työnsä on jäänyt näkyvämpien aikalaisten saavutusten varjoon, vaikka hän kuului kaupungin keskeisiin kulttuurivaikuttajiin kahden vuosikymmenen ajan (1836-1856). ${ }^{5}$ 
Artikkelissa tarkastellaan erityisesti Ignatiuksen toimintaa lehtimiehenä ja kirjailijana sekä hänen ammatillisten verkostojensa merkitystä paikallisen seuratoiminnan järjestäytymiselle. Tavoitteena on sekä selvittää hänen henkilökohtaisia vaikuttimiaan VSKS:n perustamiseen että hänen työskentelyään seurassa. Artikkelin lopuksi arvioidaan syitä siihen, miksi Ignatiuksen elämäntyöhön ei ole aiemmin juuri kiinnitetty henkilö- tai kirjallisuushistoriallista huomiota. ${ }^{6}$

Artikkelin alkuperäislähteinä on käytetty SKS:n ja Svenska Litteratursällskapet i Finlandin kirjallisuusarkistojen kirjeenvaihtoa (1839-1856) sekä VSKS:n pöytäkirjoja ja toimintakertomuksia vuosilta 1845-1859. Alkuperäislähteisiin kuuluu myös Ignatiuksen kirjallinen tuotanto: sekä Sanan Saattaja Viipurista -lehden tekstit että hänen kirjoittamansa tai kääntämänsä kansankirjaset. Henkilökohtaisten aineistojen vähäisyyttä kompensoivat esimerkiksi Ignatiuksen elämänvaiheita valaisevat muistokirjoitukset.

\section{IGNATIUKSEN ELÄMÄN VARHAISVAIHEET FENNOMAANISEN HERÄTYKSEN SELITTÄJINÄ}

K. H. J. Ignatiuksen varhaisten elämänvaiheiden kautta voi hahmottaa, minkälainen henkilökohtainen projekti teki hänestä suomenkielisen seuratoiminnan käynnistäjän. Ignatius oli syntynyt itäsuomalaiseen pappissukuun Vanhassa Suomessa, Ruokolahden kappeliseurakunnassa Rautjärvellä vuonna 1809. Hänen isänsä toimi 1810-luvun alussa Joutsenon kirkkoherrana ja Lappeenrannan piirikoulun opettajana, mutta kuoli jo pojan ollessa alle 2-vuotias. Karl Henrik Jakob itsekin oli lapsesta asti sairaalloinen. Keuhkotuberkuloosi piinasi häntä jo varhain, ja lukeminen ja kirjoittaminen toivat sairasvuoteelle ajanvietettä ja olivat keino paeta kipujakin. Ruokolahden seudulla hän oppi suomenkielisten keskellä suomen kielen täydellisesti, mutta tarjolla olleet lukemistot lienevät 1810-luvulla olleet ensisijaisesti ruotsin- tai saksankielisiä.

Sairastelusta huolimatta Ignatius kävi Viipurin saksankielisen piirikoulun ja läpäisi vuonna 1827 myös saksankielisen lukion erinomaisin arvosanoin. Hänen teologian opintonsa Helsingissä Keisarillisessa Aleksanterin yliopistossa huipentuivat 23-vuotiaana pappisvihkimykseen Porvoossa kesäkuussa 1833. ${ }^{7}$

On mahdollista, että Ignatius koki jonkinlaisen kansallisen herätyksen jo Viipurin saksankielisessä lukiossa opiskellessaan. Tuolloin sen yliopettajana ja rehtorina näet toimi Turun romantiikan aikana kansallisen kipinän saanut A. J. Europaeus, jolle kansankoulutus oli lähellä sydäntä. Myöhemmin Europaeuksesta tuli muun ohella rovasti, teologian tohtori ja historiantutkija. ${ }^{8}$

Ylioppilasaikojensa Helsingissä 1830-luvun alussa Ignatius joka tapauksessa syttyi runebergilaisesta romantiikasta. Sen osoittaa muun ohella pitkä ylis- 
tysruno J. L. Runebergille, jonka hän julkaisi myöhemmin (1840) lähes ensi töinään Sanan Saattaja -lehden päätoimittajana. ${ }^{9}$

Romanttiseen kansallistunteeseen yhdistyi myös intohimo kansankieleen. Sen kirjallisen viljelyn käynnistämisestä Ignatius antoi ansion viipurilaiselle valistuskirjailijalle Jaakko Juteinille, jolle hän kirjoitti vastaavanlaisen eeppisen kiitosrunon kuin Runebergillekin. Vaikkei hengenmiehiä kärkevästi arvostellut Juteini ollut vielä Ignatiuksen kouluvuosien kaikkien seudun pappispiirien suosiossa, Ignatiuksen kirjailijanuraa luonnehtivat myöhemmin monet jo Juteinin tuotannosta tutut elementit: etenkin ajatus suomen kielen sorretusta asemasta ja kannustaminen nuhteettomaan elämään. ${ }^{10}$

Ignatius päätyi kotiseudullaan papinsijaisuuksia hoidettuaan takaisin Viipuriin vuonna 1836, ensin vankilan ja vuonna 1838 työ- ja ojennuslaitoksen sekä suojeluksettomien lasten kasvatuslaitoksen saarnaajaksi. Työmaillaan Ignatius sai kosketuksen kaikkein vähäosaisimpiin - vankilassa rikollisiin, työ- ja ojennuslaitoksessa irtolaisiin ja alkoholisteihin, kasvatuslaitoksessa taas osattomiin orpolapsiin. Tehtävät aikuisten parissa olivat kaukana kiitollisesta. Työ- ja ojennuslaitoksiin passitettiin alkoholisteja ja "pahantapaisia irtolaisia", joita koetettiin raskasta ruumiillista työtä teettämällä parantaa siveellisiksi alamaisiksi. Ojentamiskeinoihin kuului myös papiston antama kristillinen moraalikasvatus, josta tosin vain ani harva laitoksen asukki otti opikseen."

On ilmeistä, että orpolasten, ojentolaisten ja rikollisten elämänkohtalot - siinä kuin 180o-luvun alkuvuosikymmeninä suosiossa olleet filantrooppiset vankeinhoidon aatteet - saivat Ignatiuksen vakuuttumaan rahvaan moraalin kohentamisen tarpeesta. Hän ryhtyi luomaan sille edellytyksiä tarjoamalla köyhimmälle kansalle mahdollisuuden parantaa usein alkeellista tietämystään kristinopista. ${ }^{12}$ 
Liityttyään Helsingissä SKS:n jäseneksi vuonna 1839 Ignatius aloitti työnsä kansanvalistajana: kirjailijanimellä Jaakko Jaakonpoika hän laati alkeisopetukseen tarkoitetun aapisen Tarpeellinen Lasten-kirja, jonka Frenckellin kirjapaino julkaisi Helsingissä 1840. Aakkosten ja laskuopin alkeiden lisäksi kirjan opetukset ja lukuharjoitukset koostuivat tärkeimmistä uskonkappaleista ja rukouksista, joita oli koottu Raamatun ja katekismuksen teksteistä. Lapsia kehotettiin rakastamaan ja pelkäämään Jumalaa, kunnioittamaan isää ja äitiä, vanhempia puolestaan kasvattamaan lapsensa kurissa. Opetusteksteissä lapsia kehotettiin ahkeruuteen, nöyryyteen ja armeliaisuuteen köyhiä ja ikääntyneitä kohtaan. ${ }^{13}$

Lastenkirjan sisällössä ei ollut mitään huomiota herättävää; se heijasteli 160o-luvulta jatkuneen huoneentaulun ajan perusarvoja. ${ }^{14}$ Kirjan sisältö asettui silti vastakkain toisen vastaavanlaisen suomenkielisen alkeisoppikirjan, Jaakko Juteinin Lasten kirjan $(1816,1819,1826)$ kanssa, jossa raamatullisia elementtejä oli jo korvattu maallisemmallakin sisällöllä. Nähtävästi Ignatius julkaisi oman lastenkirjansa vaihtoehdoksi papiston kanssa aiemmin kiistelleen maallikko-Juteinin alkeisoppikirjalle. Sen suosiota Jaakko Jaakonpojan teos ei silti saavuttanut. ${ }^{15}$

Lastenkirjansa julkaisun aikoihin vuoden 1840 alusta Ignatius otti tehtäväkseen myös Sanan Saattaja Viipurista -sanomalehden päätoimittamisen. Lehti oli aiemmin (1833-1836) ilmestynyt Juteinin ja neljän viipurilaisen papin toimittamana, mutta lopetettu tilaajapulan takia. ${ }^{16}$ Ignatius kertoi toimituksellisista tarkoitusperistään lehtensä ensimmäisen numeron johdantotekstissä: hän toivoi Suomen papistolta apua taisteluun nuorison juopottelua vastaan, tässä tapauksessa tarjoamalla sille hyödyllistä kansankielistä ajanvietettä.

Minä halajan Suomalaisen nimen kunniaa niinkuin Tekin, minulla on sama tarkoitus kuin Teilläkin, Suomen kansan hyödytys; yksi vihollinen minulla kuin Teilläkin, jota vastaan minä nyt Teihin luottamalla olen vähillä varustuksilla liikkeelle lähtenyt. Te tiedätte että laumassanne on paha tapa yhä yhtymäisillään, se on nuorten halu väkeväin juomain ylenpalttiseen nautintoon.

Minä keviä Lento-Lehti soisin siis että Te minua maakunnan käsiin saattaisitte, toivoen että minä siellä voisin ehkä muutaman nuorukaisen Pyhäpäivänä viivytellä vanhain joukossa ja kukatiesi vähillä ja halvilla tuomisillani vähitellen vetää ja haukutella turmelevaisesta kylänkäymisestä hyödyllisemmän ajanvietteen etsimiseen, ja niin vihtoin herättää hänessä tiedon-halun, hurskauden ja kaikkinaisia terveellisiä tapoja. ${ }^{7}$

Vaikka Ignatiuksella oli ojentolaisten sielunpaimenena erityisen omakohtaista tuntumaa juoppouden lieveilmiöihin, toive kansan kannustamisesta kehittä- 
vien harrastusten pariin oli ominainen muillekin pappisfennomaaneille - ja esimerkiksi Ignatiuksen virkaveljelle maakunnan pohjoisosassa, rukoilevaisjohtaja Henrik Renqvistille (1789-1866), joka julkaisi 1830-1840-luvuilla muun hartauskirjallisuuden ohessa kymmenittäin viinapirua vastaan suunnattuja kansanvihkosia. $^{18}$

Ignatius sai Sanan Saattajaansa sananlaskuja, arvoituksia ja uudissanoja muun ohella Elias Lönnrotilta ja Wolmar Schildtiltä (Kilpiseltä), samoin muutamia runoja Jaakko Juteinilta. Päätoimittaja puolestaan kirjoitti lehteen hengellisiä valistustekstejä, eeppisiä kalevalamittaisia runoja ja monenlaista maatalousoppia, kuvauksia vierailta mailta ja uutisia maailman teknisistä edistysaskeleista - esimerkiksi uskomattoman nopeakulkuisesta "englantilaisesta höyryvaunusta". ${ }^{19}$

Ignatius selvästi jatkoi Jaakko Juteinin aloittamissa aihepiireissä eli opetusrunoudessa, joka toisaalta ylisti suomalaisuuden sankareita (Juteini, Runeberg), toisaalta varoitti turmiollisesta elämäntavasta. ${ }^{20}$ Aiemmin mainitussa ylistysrunossaan Juteinille Ignatius osoitti "-g-"-nimimerkin takaa kunniaa maistraatin sihteerin virasta eläkkeelle jääneelle valistuskirjailijalle. Hän kiitti tätä yksinäisestä työstä suomen kielen hyväksi aikana, jolloin sen elinvoimaan ei vielä kukaan uskonut. Runoilija toivoi Juteinin voivan eläkepäivinään omistautua uudelleen suomenkielisen kirjallisuuden edistämiseen. ${ }^{21}$

\author{
Jakob Juteinille [katkelma] \\ $[--]$ \\ Mutta Sinä siivon suopa \\ Sinä jäykkä-jäseninen, \\ Suomalainen syntymästä, \\ Meidän mielenkin halusta, \\ Ennen muinon elämäsi \\ Laittelit keväällä kerran \\ Kaikki kalut taitavasti, \\ Kävit sitten vaan kädellä \\ Yhdellä ja yksinäsi \\ Oman nerosi ojassa, \\ Varustukset jo varana, \\ Yhdellä yrityksellä
}


Tuosta noin vaan tunkemahan

Auraa ahkerikko-maahan,

Mehuttomaan meidän kielen

Siksi sitä moni luuli -

Urhollinen, uuras miesi!

$[--]$

Jaakko, jalo viran töissä,

Laulun latoja Juteini!

Selvä seppä Viipurissä,

Sinä kalun kaunihimman

Sekä terien tekiä

Harvinainen, Hattulasta!

Kauvan nähnyt nuhjumista,

Kauvan kuullut kolkkumista,

Paljo palkeen pauhumista

Viipurista, viimein kerran

Kyllästyneenä kysyypi

Suomen suku jo Sinulta:

"Mitäs miitit, mies, niin kauvan?

Kyllä on jo odotettu

Saita saavan säästöstäsi

Rikkahasta riemuksemme,

Näpistäsi nähdäksemme

Oman pellon, perkaamasi,

Kaunihia kasvannoita.

Sillä vaikka kalut kaikki,

Vaiva, vahvuus käsi-varren

Sinun ovat osinkota,

Ystävämme, yhteisestä

Pelto-maasta maksettava

Ompi toki osa-lyhde. 
Runebergille osoittamassaan runossa Ignatius puolestaan luki kansallisrunoilijan ansioksi yleissuomalaisen tietoisuuden synnyttämisen ja Suomen kokonaisuuden tunnetuksi tekemisen - "vieraan kielenkään" näitä saavutuksia himmentämättä. Siinä missä Ignatius rinnasti Juteinin kirjallisen toiminnan moninaisia työvaiheita vaativaan maanviljelykseen, hän käytti Runebergin runoilijantyön metaforana Väinämöisen kanteletta. ${ }^{22}$ Yhteistä runoille oli kalevalainen mitta ja sepän taonnan nostaminen sanankäytön vertauskuvaksi.

\section{J. L. Runebergille [katkelma]}<smiles>C1[IH][IH]1</smiles>

Runebergi; Runo-seppä, Takoja takana vuorten!

Sukulainen, seikko olet Veli, veikko jokaiselle Suomen maassa syntyneelle, Maahansa mielistyneelle:

Sillä vaikka vieraat kielet Kanteleessas kuuluvassa, Muoto toki tuuttavaksi Tunnetaan jo tuhansilta.

Kanteletta Väinämöisen Käsivartes' kannattaapi;

Kansi tuotu Kainun maalta, Pohja peri-Pohjolasta, Savostapa sivut saadut, Kaula tehty Karjalassa, Niveet, nauhat Hämehestä.

Tuttu Suomi on sinulle Laitumet ja lammit kaikki, Taivas tuttu tähtinensä, Viluinensa, varinensa, 
Lumet, hanget, hiihtämiset,

Mäen laskut, liukumiset;

Tupain tavat tiedyt kaikki,

Pidot, riemut, leikit, laulut

Tutut ovat tutkineelle.

Laula näitä lakkaamata.

Ignatius julkaisi Sanan Saattajassa myös opettavaisia sananparsiaan ja aforismejaan. Osa niistä kohdistui oikeuslaitoksen epäkohtiin, jotka 1840-luvulla olivat moninaiset. Muuhun Suomeen nähden Viipurin läänin asukkaat esimerkiksi haaskasivat rahojaan moninkertaisesti erilaisista pikkujutuista käräjöimiseen ja työllistivät näin suuren määrän epäpäteviä oikeusapureita. ${ }^{23}$ "Karta käräjän-käyntiä jos suinkin voit välttää. Sananlasku kyllä väittää papin säkin pohjattomaksi, [mutta] koetus erää tuomarin kormanon [taskun] pohjattomammaksi." ${ }^{24}$ Kerrottuaan itsemurhaan päätyneestä Antista, joka oli petollisen "komsarjuksen" neuvoista menettänyt omaisuutensa ja saanut tuomion asiakirjan väärentämisestä, Ignatius opasti: "Laissa ja oikeudenkäynnissä outo. Älä luota mokomiin komsarjuksiin joilla on tovereina joukko kersantteja lukkaria ja muita nurkka sihtieriä." ${ }^{25}$ Vilpillisiin oikeusavustajiin kohdistuneiden moitteiden syynä saattoivat olla laitossaarnaajan todistamat ihmiskohtalot tai Jaakko Juteinin esimerkki monenlaisten pikkuviskaalien arvostelijana. ${ }^{26}$

Laajemmin lehden yhteiskuntakritiikki silti kohdistui pääasiassa suomen kielen huonoa asemaa kohtaan. Tällainen arvostelu erotti Ignatiuksen ajan Sanan Saattajaa lehden aikaisemmasta toimituksellisesta linjasta. ${ }^{27}$ Se myös luo yllättävää särmää muilla elämänaloilla sovittelevaksi tiedetyn hengenmiehen profiiliin.

Ignatius joutui lopettamaan Sanan Saattajan vuoden 1841 lopussa, koska sisältöä ei ollut riittävästi. Viimeisenkin mahdollisuuden lehden jatkamiseen vei päätoimittajan pitkä vihkimatka Luvialle, jossa hän avioitui Selma Favorinin kanssa heinäkuussa 1842. Kirjeessään Elias Lönnrotille Ignatius suri syvästi lehden lopettamista ja valitteli, ettei ollut saanut ketään "tätä palkatointa työtä vaivoiksensa ottamaan”. Valkeasaaren kirkkoherra, runoilija Konstantin Schröder, joka oli aiemmin auttanut toimitustyössä, oli "kivulloisuuden takia jättänyt [hänet] ypö yksin”, eikä Carl Henrik Ståhlberg, lukion yliopettajaksi vastikään nimitetty SKS:n perustajajäsen, "halunnut puuttuakaan koko asiaan". ${ }^{28}$ Sanan Saattajan viimeisen numeron päätti paljonpuhuvasti rautalampelaisen lautamiehen Pentti Lyytisen runo "Suomen kielen ylenkatseesta". ${ }^{29}$ 


\section{OPETTAJAN JA KIRJAILIJAN URALLE}

Uuden haasteen Ignatiukselle antoi joulukuussa 1841 alkanut apulaisopettajan viran hoito Viipurin lukiossa, jonka opetuskieli oli lukukauden alussa vaihtunut saksasta ruotsiksi. ${ }^{30}$ Ignatiuksen lämpimät ajatukset isänmaasta ja kansankielestä sopivat hyvin koulun suomalaishenkiseen ilmapiiriin, sillä sen opettajakuntaan oli 1830-luvun loppupuolelta lähtien tullut muitakin nuoria opettajia, jotka olivat yliopistovuosinaan kokeneet runebergilaisen herätyksen. ${ }^{31}$ Työskentelypaikkakunta oli suomenmielisille opettajille kenties mieluisin mahdollinen, koska Viipuri oli eteläisen rannikon ainoa lukiokaupunki, jonka pääväestö oli suomenkielistä. Kaupungin säätyläis(mieh)istäkin suuri osa osasi kieltä ainakin auttavasti. ${ }^{32}$ Lukion fennomaaniopettajien joukkoa täydensi syksystä 1841 myös yliopettajaksi tullut Carl Henrik Ståhlberg, joka entisenä lauantaiseuralaisena, SKS:n perustajajäsenenä ja sihteerinä kuului suomalaisten kulttuurifennomaanien eliittiin. Ignatius sai hänestä työparin suomalaisuusrientoihinsa, vaikka Ståhlberg aiheuttikin sanomalehtiasiassa Ignatiukselle pettymyksen. ${ }^{33}$

Sanan Saattajan lakkauttamisen jälkeen Ignatius suuntasi kirjallista energiaansa käännöstöihin, vaikka toimi jatkuvasti myös kahdessa, kolmessa tai neljässä pappis- ja opetustehtävässä. Omistautumista vaati myös kasvava perhe; Ignatiuksen ja Selma Favorinin avioliittoon syntyi vuosina 1843-1849 neljä lasta, joista kolme varttui aikuisikään asti. ${ }^{34}$

Vuonna 1843 Ignatius julkaisi Porvoossa - edelleen Jaakko Jaakonpoikana - kaksi käännettyä teosta: saksalaisen ekumeenisen saarnaajan Johannes Gossnerin hartauskirjan Jesus ihmisen sydäntä kolkuttava sekä filosofin, keksijän ja Yhdysvaltain yhden perustajaisän, Benjamin Franklinin, suositun teoksen Neuvoja kaikille säädyille rikkaaksi ja onnelliseksi päästäksensä. Franklinin kokoelma sisälsi aforismeja, jotka sopivat työteliäisyyttä korostavaan luterilaiseen arvomaailmaan. Teos on ikivihreä elämänopas, sillä siitä oli jo ennen Ignatiuksen käännöstä julkaistu kaksi suomennettua laitosta ja sittemmin lukemattomia lisää; mainittakoon, että teoksen myöhempiin suomentajiin kuului myös viipurilaiskirjailija Kersti Bergroth. ${ }^{35}$

Ignatius tarjoutui 1840-luvun alussa kääntämään SKS:lle muitakin kansankirjoja, mutta seuralla ei ollut tähän resursseja, koska sen varat ohjattiin tässä vaiheessa pääsääntöisesti kansanrunouden keruuseen ja tutkimukseen. Yksittäisten omakustanteiden ja hartausvihkosten lisäksi suomenkielisiä kansanvalistuskirjoja julkaisi aktiivisesti vain Savo-Karjalainen osakunta. Osakunta laati oman kansanvalistusohjelmankin, johon kuului sekä sanomalehden että valistus- ja oppikirjojen julkaiseminen. ${ }^{36}$ Savon ja Pohjois-Karjalan ylioppilailla oli siis samanlaisia päämääriä kuin Ignatiuksella, mutta nähtävästi maantieteellinen ja kenties henkinen etäisyys estivät yhteistyön syntymisen. 


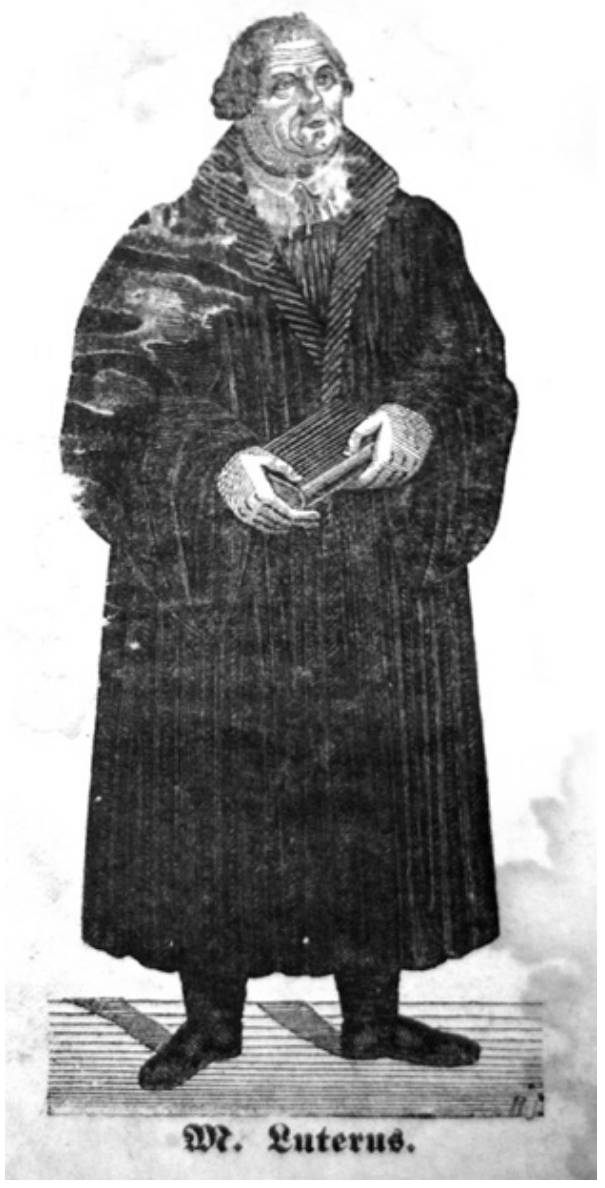

Nimihenkilön uhkeaa olemusta kirjan Martti Luterus kansilehdeltä.
Kohtuullisen hyvän vastaanoton saaneiden käännösteostensa jälkeen Ignatius perusti sarjan Lukemisia Suomen kansalle, jossa oli tarkoitus julkaista opettavaisia ja hengellisesti kohottavia kansankirjasia. ${ }^{37}$ Syystä tai toisesta sarjan nimi muistutti huomattavasti Savo-Karjalaisen osakunnan maallisempaa valistuskirjasarjaa, jota julkaistiin nimellä Lukemisia Suomen kansan hyödyksi. Ignatiuksen Lukemisia-sarjaa julkaisivat helsinkiläiset kirjapainot Wasenius ja Frenckell, mutta taloudellista riskiä julkaisemisesta kantoi nähtävästi myös Ignatius itse.

Lukemisia-sarjan teokset Ignatius julkaisi ristimänimellään. Syy aiemmasta Jaakko Jaakonpoika -kirjailijanimestä luopumiseen jää lähteiden puuttuessa avoimeksi, mutta syy ei varmastikaan ollut se, mitä piikikkääksi tiedetty Johan Vilhelm Snellman Saima-lehdessään epäili, eli Ignatiuksen "halu välttää kirjailijanimensä tärveleminen sen suomalaistamisella". ${ }^{38}$ Olihan Ignatius ehtinyt jo julkaista kolme teosta suomenkielisen nimimerkin takaa.

Lukemisia-sarjan ensimmäinen vihko, Harjulan onnettomuus (1845), edustaa varhaista suomenkielistä raittiuskirjallisuutta ja on lajityypissään katsottu aikansa parhaimmistoon. Se kuvaa viinanjuonnin kirouksia, jotka ajavat kaksi veljestä perikatoon. Sairastelevaa Ignatiusta auttoivat sen julkaisemisessa Elias Lönnrot ja suomen kielen ja kulttuurin edistämisestä innostunut historioitsija Matthias Akiander. ${ }^{39}$ Lehtiarvioissa kirjaa kiiteltiin sekä kansaa kasvattavasta sisällöstä että kauniista ja korrektista suomen kielestä, vaikka teoksen moralistiset asetelmat olivat akateemisille lukijoille turhan yksioikoisia. ${ }^{40}$ Sivistyneistö ei tosin kirjan kohderyhmää ollutkaan. Vastaavanlaisten valistavien moraliteettien perinteen oli aloittanut SKS kääntämällä Heinrich Zhokken teokset Kultala (1834) ja Viinamyrkystä surullinen tarina (1844). Tämän jälkeen Helsingin seura keskittyi suomen kehittämiseen sivistyskieleksi. ${ }^{41}$

Ignatiuksen kirjat levisivät huomattavan laajalle. ${ }^{42}$ Valkeasaaren runoilevan kirkkoherran Konstantin Schröderin avulla osa Harjulan onnettomuuden 3000 kappaleen painoksesta levisi Inkerinmaan seurakunnissa, kunnes myös Turun arkkihiippakunta hankki teoksia Porvoon tuomiokapitulin suosituksesta jakaakseen Suomen seurakuntiin. ${ }^{43}$ Pian Harjulan onnettomuuden jälkeen ilmes-

142 | SUOMENKIELISEN KIRJALLISUUDEN KAUPUNKI 
tyi ja myytiin loppuun myös Lukemisia-sarjan toinen teos, parisataasivuinen elämäkerta Martti Lutherista. ${ }^{44}$ Martti Luterusta J. V. Snellman luonnehti hiukan pateettiseksi, vaikka toivoikin Ignatiuksen "hyviksi tiedettyjen ja moitteettomasti kirjoitettujen" teosten leviävän kansan pariin. Snellman ei suhtautunut Ignatiuksen tuotantoon hengellisenä hartauskirjallisuutena, vaan luonnehti teoksia hyödyllisiksi kansankirjasiksi. ${ }^{45}$

\section{VSKS:N PERUSTAMINEN}

Jatkuvaksi tarkoitetun Lukemisia-sarjan ilmestyminen päättyi yllättäen jo Martti Luterukseen. Syynä oli julkaisuolosuhteiden muuttuminen käänteentekevästi syyskuussa 1845: tuolloin perustettiin "Suomalaisen Kirjallisuuden Seura Viipurissa". Sen perustamisvaiheen aloitti Saimassa huhtikuun puolivälissä ilmestynyt J. V. Snellmanin lehtikirjoitus, jossa ehdotettiin Suomalaisen kirjallisuuden seuran maaseudulla toimivien kirjeenvaihtajajäsenten määrän moninkertaistamista. Näiden tehtäviksi Snellman näki jäsenmaksun kantamisen ja karhuamisen, jottei maksuja tarvitsisi periä Helsingistä käsin. Jäsenmaksun vastineeksi kirjeenvaihtajat järjestäisivät paikkakunnalla vuosikokouksen, ja sen yhteydessä pidettävässä vuosijuhlapuheessa levitettäisiin tietoa SKS:n toiminnasta ja kannustettaisiin yleisöä SKS:n työaloille. Myös käännöskaunokirjallisuutta tai suomenkielistä alkuperäiskirjallisuutta voitaisiin jakaa mahdollisuuksien mukaan. ${ }^{46}$

Käytännössä Snellmanin esittämät kirjeenvaihtajajäsenet olisivat siis organisoineet maakuntiin SKS:n apuseuroja. Tällaisten filiaalien jäseniksi Snellman suositteli hyväksymään myös naisia, koska näin rakkautta isänmaahan ja suomalaiseen kirjallisuuteen voitaisiin herättää myös sivistyneen säädyn rouvasväen ja neitosten parissa.

Toukokuun puolivälissä Pietari Hannikaisen viipurilainen sanomalehti Kanava julkaisi samaa asiaa suomeksi käsittelevän Wolmar Schildtin (Kilpisen) kirjoituksen. Kilpinen katsoi Snellmanin tavoin, että SKS:n filiaalit eli "apuyhteydet" vuosijuhlineen olisivat tarpeellisia SKS:n tiedotuskanavia. Hänkin oli valmis hyväksymään naiset seuran jäseniksi - tosin vedoten ensisijaisesti siihen, että neitosten läsnäolo houkuttelisi seuratoimintaan vastakkaistakin sukupuolta: "josko [naiset] tulisivat niin totta ihanaisten kauniista esimerkistä monen nuorukaisenkin sydän syttyisi kotikieleen ja kirjallisuuteen." ${ }^{47}$

Toivotunlaisia SKS:n "apu-yhteyksiä" ei lopulta syntynyt minnekään päin Suomea, vaikka uusia asiamiehiä nimitettiinkin. ${ }^{48}$ Sen sijaan Viipurissa käynnistettiin huomattavasti suurisuuntaisemmat suunnitelmat kuin Snellmanin ja Schildt-Kilpisen lehtikirjoituksissa oli tavoiteltu: tavoitteeksi ei tullut filiaalin, vaan itsenäisesti toimivan kirjallisuusseuran perustaminen. 
Schildt-Kilpisen kirjoituksesta Kanavassa innostui erityisesti K. H. J. Ignatius, ja syykin lienee selvä: vaikka hän koki tarvetta edistää suomenkielistä julkaisemista myös laajemmin, erityisesti hänen omat kirjansa olivat vailla pysyvää kustantajaa. Kustannustoiminta oli kallista ja markkinat kannattamattoman pienet. Siksi tekijöitäkin toisaalta kannustivat enemmän aatteelliset motiivit kuin toive taloudellisesta hyödystä. Toisaalta Viipurin kieliolot olivat suomenkieliselle julkaisemiselle paljon Helsinkiä tai Turkua otollisemmat. Lisäksi Ignatiuksella oli pappina ja entisenä lehtimiehenä toimivat kontaktit suomen kielen ja kirjallisuuden edistämisen kannalta keskeisiin tahoihin Viipurissa: erityisesti lukion opettajiin ja Sanan Saattajassa suomeksi julkaisseihin vaurastuneisiin kansankirjailijoihin. Heitä olivat esimerkiksi Jaakko Juteini ja kauppias-runoniekka Adam Wilke. Muualta Suomesta Sanan Saattajan aikaiseen verkostoon kuuluivat esimerkiksi Lönnrot, Schildt-Kilpinen ja monet maaseudun kansankirjailijat. ${ }^{49}$

Aivan ensimmäisenä Ignatius tiettävästi keskustelikin kirjallisuusseura-asiasta hyvän ystävänsä Hackmanin kirjanpitäjän, pikkukauppias Adam Wilken kanssa. Wilke oli syntynyt Lappeella pientalollisen pojaksi, mutta päässyt piirikouluun ja kivunnut ammattitaitonsa ansiosta viipurilaiseen keskiluokkaan. ${ }^{50}$ Wilken jo pitkään kypsyneet toiveet suomen kielen aseman parantamisesta käyvät ilmi ilahtuneesta runotervehdyksestä, jonka hän oli lähettänyt Sanan Saattajan alkutaipaleelle maaliskuussa $1833 .{ }^{51}$

\section{Katkelma Wilken runosta Sanan Saattajalle:}

Suo Jumala

Suomen miehen Suomen mielen,

Suomen kielen,

Joka ompi pimiässä,

Hämärässä, häpiässä,

Kauvan ollut onnetoina,

Tiedon tiellä toimetoina,

Tulla viimein valaistuksi!

Suo myös niiden suosiota,

Jotka Sanan Saattajiksi

Olon ottiit oivallisen

Vielä meidän Viipurissa,

Suomen Suola-kaupungissa,

Karjalaisen kartanossa,

Savonmaan Salon Kylässä; 
Että mielen yhtyydellä

Työtä tehdä taitaisivat

Kansakunnan kunniaksi,

Suomen miehen miel-hyväksi,

Opiksi oman sukumme,

Eikä vierainkan vihoiksi!

Aina ompi onni ollut

Jokaisen myös joukon luonto,

Kansan kaiken kallis lahja

Osatessa omaa kieltä,

Taitaessa tarinoita

Lausutella, lasketella

Vallan kaiken kasvannosta,

Vanhoista Esi-Isistä.

Ei siis outo olisikan

Jos myös mekin Suomalaiset,

Sattuisimme sillen tiellen,

Jota myöden matkustella

Olisipa oivallinen,

Kirjoitellen kaikenlaista

Lukioillenkin eduksi!

$[--]$

Mutta joskas saattaisimme,

Hirviäisin hiiskutella

Mitä ompi mielessäni,

Niin mä, Suomi, sullen soisin,

Että kieles kaunihisti

Kirjoitettais' Opistossa

Kuin myös Oikeuksissakin,

Kouluissa ja Käräjissä,

Oman kansan kunniaksi,

Ymmärrykseks' yhteiseksi,

Että taitais' Talonpoika

Itse saada ilmestyksen

Käräjänsä käymisestä,

Omista jutuistansakin. 


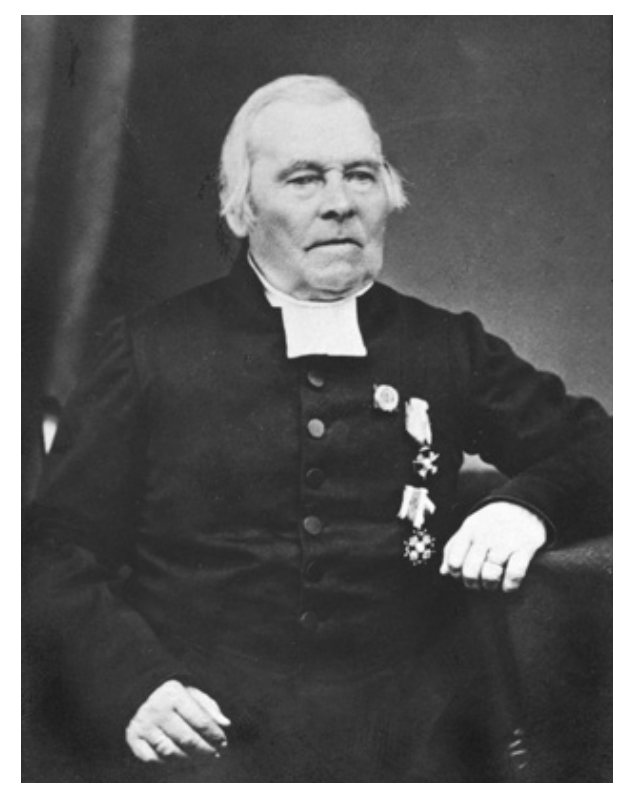

Pielaveden kirkkoherraksi 1850-luvun puolivälissä siirtynyt Carl Henrik Ståhlberg kabinettikuvassa vanhoilla päivillään.

Wilken ohella Ignatiuksen oli luontevaa ottaa kirjallisuusseuran organisoiminen puheeksi lukiolla esimiehensä, yliopettaja Carl Henrik Ståhlbergin kanssa. Ajatus viipurilaisen seuran perustamisesta näet väistämättä joko etenisi tai kaatuisi Helsingin Suomalaisen Kirjallisuuden Seuran perustajajäsenen mukana. Ståhlberg kannatti ilman muuta paikallisten kirjallisuuspiirien järjestäytymistä, vaikka olikin innostuneempi runonkeruuretkien tukemisesta kuin kirjojen julkaisemisesta. ${ }^{52}$

Ajatus viipurilaisesta kirjallisuusseurasta esiteltiin epäilemättä nopeasti myös Jacob Judénille - Jaakko Juteinille - jonka ansiot suomenkielisen kirjallisuuden tuotteliaana tienavaajana olivat tuohon aikaan ylivertaiset koko suuriruhtinaskunnassa. ${ }^{53}$ Tosin Judén ei ehkä olisi välttämättä halunnut toimia SKS:n apuseurassa, koska ei ollut Helsingin SKS:nkään jäsen. Nähtävästi häntä pitivät pääkaupungin kirjapiireistä loitolla vanhat kirjalliset kiistat papiston kanssa. ${ }^{54}$ Juteinin suhtautuminen SKS:ään saattoikin olla yhtenä syynä siihen, että Viipurin seura päätettiin perustaa SKS:stä erillään. Niin Ståhlbergin kuin kuin Juteininkin seurusteluhaluja Helsingin eliittipiirien kanssa saattoi hillitä sekin, että molemmat olivat päätyneet Viipuriin koettuaan Helsingissä tappion viranhaussa - Judén senaatin kielenkääntäjän virasta 1811 ja Ståhlberg suomen kielen lehtoraatista $1839 .{ }^{55}$

Mahdollisia henkilökohtaisia motiiveja tärkeämpi vaikutin itsenäisen seuran perustamiseen saattoi silti olla Helsingin SKS:n vähäinen kiinnostus suomenkielisen kansankirjallisuuden - esimerkiksi Ignatiuksen seuralle tarjoamien käännösteosten - julkaisemiseen. 1840-luvun puolivälissä seuraa arvosteltiinkin sanomalehdissä passiivisuudesta ja hiljaisuudesta. ${ }^{56}$ Viipurin kielioloissa taas suomenkielisten kirjojen julkaiseminen oli lähtökohtaisesti otollisempaa kuin Helsingissä, jonka takamaaston rahvas oli ruotsinkielistä ja säätyläiset suomen kielen ummikkoja. Jo muutaman viikon kuluttua Kanava-lehden jutun julkaisemisesta (9.6.1845) Helsingin Morgonbladet tiesikin mainita, että Viipurissa suunniteltiin kirjallisuusseuran perustamista. ${ }^{57}$

Tietä itsenäiselle suomenkieliselle seuratoiminnalle olivat Viipurissa pohjustaneet sekä Jaakko Juteinin pitkä, jo 1810 luvulla alkanut kirjallinen toiminta että paikalliset sanomalehdet, joita julkaisi paikallinen Cederwallerin kirjapaino. Ajankohtaisesti vieläkin tärkeämpää oli, että kaupungissa toimi 1840-luvun puolivälissä kaksi nuorta ja aktiivista suomenkielistä kirjoittajaa, 
Ignatiuksen ohella lehtimies-kirjailija Pietari Hannikainen. ${ }^{58}$ Nämä olivat tosin liian erihenkisiä ystävystyäkseen. ${ }^{59}$

Suunnittelutyön lopputulos, syyskuussa 1845 perustettu "Suomalaisen Kirjallisuuden Seura Viipurissa”, oli varsin kaukana Snellmanin ja Kilpisen keväisissä lehtijutuissa esitetyistä ajatuksista. Seura oli itsenäinen, vaikka sen säännöt oli reaalipoliittisista syistä kopioitu SKS:lta, joskin niihin oli lisätty maininta paikallisista tarpeista. ${ }^{60}$

Mikäli seuran perustamistarinaa kuljettaa Ignatiuksen kirjailijantyön kautta, VSKS:n syntymisen tärkeimmäksi herätteeksi osoittautuu tarve luoda kunnollinen julkaisukanava suomenkieliselle oppi- ja valistuskirjallisuudelle, koska tällaisen julkaisemisen resurssit puuttuivat Helsingin SKS:lta. Näin jäsenmaksuvarat voitiin pitää Viipurissa ohjaamatta niitä Helsinkiin, jossa ne olisi käytetty lähinnä kansanrunouden keruuretkiin. ${ }^{61}$

Tällainen vaikutin on maanläheisempi ja uskottavampi kuin Teperin tulkinta, jonka mukaan seuran perustamisen osoitti laajojen kansalaispiirien organisoitumista paikallisen kansan aseman parantamiseksi ja säätyjen välisten jännitteiden lieventämiseksi. Hänen näkemystään pohjusti osin kaupungissa 1840-luvun alussa vierailleen Herman Kellgrenin ajatus Viipurin kielisuhteiden suomalaistumisesta luonnonlain vääjäämättömyydellä. ${ }^{62}$ Vaikka myös seuran ensimmäinen esimies J. E. Bergbom nosti ensimmäisessä vuosijuhlapuheessaan seuratoiminnan tavoitteita lähes yhtä abstraktille tasolle, eivät seuran perustamis- ja alkuvaiheen asiakirjat ja kirjeenvaihto viittaa kovin kauaskantoisiin päämääriin: pikemmin toimintaa ohjasi seuran kahden opettaja-puuhamiehen tarve suomenkielisille oppikirjoille. Silti ajatus Viipurista yhtenä kieleen sidotun kansallisen ideologian keskuksena saattoi 1840-luvulla hyvinkin kohottaa paikallispatrioottisia tunteita. ${ }^{63}$

Seuran sääntöihin sisälletyn maininnan "paikallisista tarpeista" Teperi on tulkinnut vihjaukseksi lahjoitusmaaselkkausten kärjistämistä maaseudun oloista. Näin uhkarohkeasta eleestä oli tuskin kysymys: sanamuoto viittaa asiayhteydessään ennemminkin Viipurin läänin ja muunkin Itä-Suomen kielioloihin. Seuran ensimmäisessä vuosikertomuksessa Ignatius näet kuvaa perustamisvaiheiden tavoitteita seuraavasti:

\footnotetext{
Päätettiin täläläkin ruveta kokoomaan yhtä mieltä pitäviä yksiin, ja yhteisin neuvoin rakasta äitinkieltä nykyisestä halvennuksen tilasta suurempaan ansaittuun kunniaan saattaakseensa [- - Tätä ei tehty varoin ja voimiin luottaen vaan niissä toivein että meidänkin nurkasta halu äidinkieleen liene jo ehkä heräämässä, ja että maanpaikassa jossa yli ympäri on ummikko suomalaisia asumassa mahtaisi löytyä suomalaisia ei ainoastaan syntymältä vaan sydämeltä. ${ }^{64}$
} 
Lahjoitusmaakysymystä ei sivuta seuran asiakirjoissa tai jäsenten kirjeenvaihdossa.

"Suomalainen Kirjallisuuden Seuran Viipurissa" perustamisasiakirjan allekirjoitti syyskuun alkupäivinä 1845 kaikkiaan 14 henkilöä. ${ }^{65}$ Perustajissa erottautuu kaksi ryhmää: kuusi heistä oli ruotsinkielisiä lukion opettajia ja viisi taas suomenkielisiä säätynousijoita, jotka olivat tehneet uraa pääsääntöisesti ruotsin tai saksan kielillä. Jälkimmäisiin kuului myös Jacob Judén, joka sai kunnian allekirjoittaa perustamisasiakirjan ensimmäisenä. Suomenkieliseen kauppias- ja kirjanpitäjäryhmään kuuluivat puolestaan tukkukauppias Abraham Keldan ja aiemmin mainittu Ignatiuksen hyvä ystävä Adam Wilke. Ignatiuksen keskeistä roolia seuran perustamisessa kuvaa se, että viisi seuran perustajajäsentä, osa heistä vaimoineen, valittiin hänen lastensa kummeiksi. ${ }^{66}$

Edellä mainitun asiakirjan allekirjoittajien ohella seuran perustajiin luetaan 11 muutakin seuran perustamiskokoukseen syyskuun 25. päivänä osallistunutta miestä. Heihin kuuluivat muiden muassa syntyperältään vaatimaton liikemies ja kansankirjastojen edistäjä Johan Pynninen sekä sääminkiläisen lautamiehen pojaksi syntynyt maanmittari Peter Hanén, lehtimies Pietari Hannikainen. ${ }^{67}$

Seuratoiminnan organisoitumisen tekivät yhdessä mahdolliseksi suomenkielisestä julkaisemisesta innostuneet maaseudun tulokkaat ja romanttinen, osin kansankoulutuksesta innostunut lukion opettajakunta. Myös muutamat virastojen (maistraatin ja hovioikeuden) virkamiehet pitivät kansalle vierasta oikeudenkäyntikieltä ongelmana, ja moni heistä oli jo SKS:n jäseniäkin. Näin erilaisten ryhmien yhteistoiminta VSKS:ssa on osoitus kaupungin omintakeisesta kulttuurisesta dynamiikasta. Monikielisen kauppakaupungin keskustelunaiheita rikastutti erityisesti suomenkielisten pikkuliikemiesten pääsy seurapiireihin kenties jo muuta Suomea varhaisemmin. ${ }^{68}$

Vaikka seuran keulakuvana toimiva esimies rekrytoitiin hovioikeudesta, sen toimintaa johti käytännössä 1850-luvun puoliväliin saakka varaesimies Carl Henrik Ståhlberg. Ignatius taas toimi kuolemaansa asti kirjallisuusseuran sihteerinä ja kirjakaupan hoitajana. Sihteerinä hän laati - aina terveytensä salliessa - seuran pöytäkirjat ja vuosikertomukset. Valistuskirjailijana ja kääntäjänä hän pystyi kirjoittamaan molemmat suomeksi vaikeuksitta. Tämä on huomionarvoista, koska suomi voitiin ottaa Helsingin SKS:n pöytäkirjakieleksi vasta vuonna $1861 .^{69}$

Huomattavasta organisointikyvystä - jota edistivät ehkä Ståhlbergin toimet Helsingin seurassa - kertoo se, että VSKS lähetti kahtena ensimmäisenä toimivuotenaan yli 440 "jäseneksi kutsumuskirjaa". Kutsuttuja olivat komeasti niin Elias Lönnrot, J. L. Runeberg kuin J. V. Snellmankin sekä yliopiston rehtori ja SKS:n esimies Gabriel Rein ja Turun romantiikan maanpaossa ollut johto- 
mies A. I. Arwidsson Upsalasta. Kutsuttavien joukkoon oli nähtävästi Ignatiuksen lehtimiesaikaisten kontaktien perusteella etsitty järjestelmällisesti myös kirjallisesti harrastuneita talonpoikia. Vaikka SKS:n piirin kansallisen tason suurmiehet eivät liittyneet viipurilaiseen seuraan, itäsuomalaista vallasväkeä - ja rahvastakin - VSKS:n jäsenistöön rekrytoitiin varsin hyvin: vuonna 1846 Viipurin kirjallisuusseuralla oli 240 maksavaa jäsentä, joista suurin osa asui Viipurin tai Savon ja Karjalan lääneissä. ${ }^{70}$

Koska seuran jäseneksi hyväksyttiin alusta alkaen myös naisia, perustajien vaimot liittyivät seuraan näyttäen näin esimerkkiä muillekin sukupuolensa edustajille. Ignatiuksen perustelu naisten jäsenoikeudelle VSKS:ssa oli kaukonäköinen: keidenpä muiden kuin "äitien kautta [lapsissa] heräisi rakkaus ihanaan isän maahan, somaan soipaan äitien kieleen”?ㄲ Ajatus oli Ignatiuksen elämässä ajankohtainen, sillä hänen rouvansa opetteli kotona parhaillaan suomen kieltä samaan aikaan kuin perheen isä ja palvelusväki opettivat sitä ensimmäisenä kielenä lapsille. ${ }^{72}$ Toisaalta aiemmissa tutkimuksissa toistunut käsitys naisten jäsenoikeuden pohjautumisesta Vanhan Suomen, etenkin Katariina II:n ajan venäläiseen perinteeseen ${ }^{73}$ osoittautuu virheelliseksi, sillä ajatuksen naisjäsenyydestä esittivät ensimmäisinä kantasuomalaiset Snellman ja Kilpinen.

\section{IGNATIUKSEN TYÖ SEUROISSA JA KOULULAITOKSESSA}

Joistakin sattumanvaraisista päällekkäisyyksistä huolimatta VSKS:n työmuodot poikkesivat pitkälti Helsingin seurasta, jonka voimavarat kuluivat 1840-luvulla Kalevala-kultin vaalimiseen ja 1850-luvulta suomen kielen tutkimiseen, sanaston luomiseen ja suomen kehittämiseen tiedekieleksi. ${ }^{74}$ Yhteistyössä seurat toisaalta tekivät rahoittaessaan etenkin Ståhlbergin toiveesta D. E. D. Europaeuksen ja H. A. Reinholmin kansanrunouden keruuretkiä. Niin ikään VSKS tarkasti SKS:n toimeksiannosta Elias Lönnrotin teoksia. Tällaiseen työhön Viipurissa valjastettiin ennen muuta Ignatiuksen ja Ståhlbergin asiantuntemus. Myös Judén osallistui seuran ensimmäisiin kokouksiin ja oli nimettynä muutamaan lohkokuntaankin, mutta hänen panoksensa seuran työhön jäi vähäiseksi. ${ }^{75}$ Hänen kirjallinen esimerkkinsä silti ohjasi seuran julkaisuohjelmaa hyödyllisen kansankirjallisuuden suuntaan: kansaa ei voinut kirjallistaa ellei kansankielistä kirjallisuutta ollut saatavilla.

VSKS:n varaesimies Ståhlberg kiteytti myöhemmin Viipurin seuran päätarkoituksena olleen alusta alkaen sellaisten kirjojen julkaiseminen, jotka "tarkoittavat kansallista valistumista, maaruukin parantamista ja erinomattain suomalaisten koulujen tarvetta”. Suuntautumista osoittivat jo VSKS:n varhaisimmat toimet. Asialistalle tuli ensimmäisenä etsiä "seuran tarkoitukseen so- 


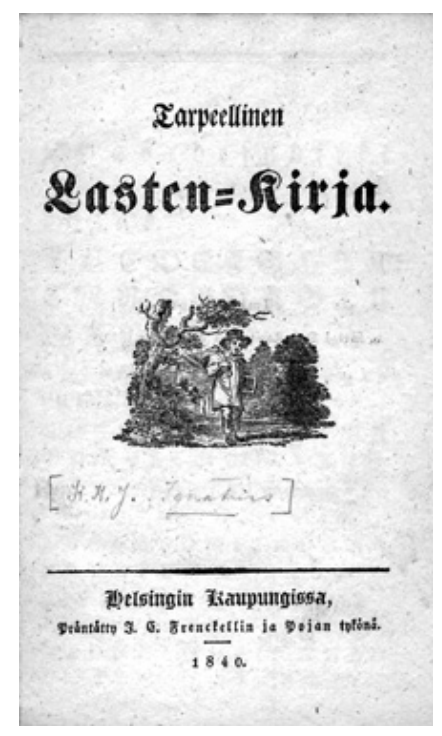

Ignatiuksen Tarpeellinen Lasten-kirjan kansilehti vuodelta 1840 .

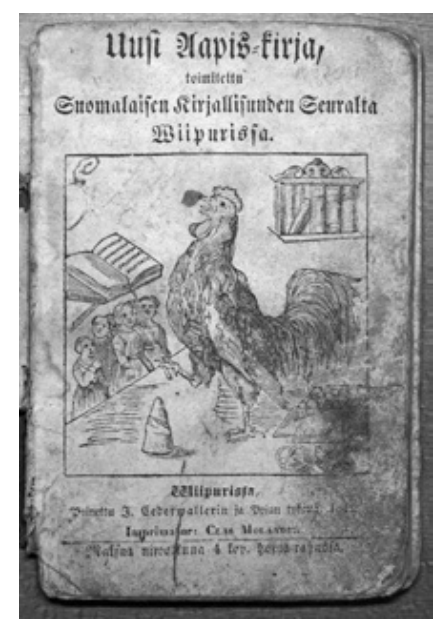

Aapis-kirjan painattaminen toi Cederwallerin kirjapainolle niin runsaat tulot, että yritys lahjoitti seuralle aapiskukon kuvan, joka sijoitettiin jatkossa kirjan nimiösivulle. Kuvassa eturivin koulukkaat ovat tyttöjä, joita Vanhassa Suomessa oli voitu 1780-luvulta lähtien kouluttaa pidemmälle kuin muun Suomen puolella. ${ }^{78}$ pivia käsikirjoituksia - erityisesti suomen kansan lapsille ja nuorisolle kotona, sunnuntai ja pitäjäkoulussa käytettäviä aapisia eli aapeluksia, oppikirjoja ja lukutauluja". ${ }^{76}$

VSKS:n ensimmäisessä, julkaistavaksi soveltuvia oppikirjoja selvittävässä lohkokunnassa todettiin, että seuran tarkoitusta vastaava aapinen oli käytännössä jo olemassa. Kyseessä oli Ignatiuksen Jaakko Jaakonpoikana julkaisema Tarpeellinen lasten kirja (1840). Sen katsottiin sopivan "vain vähäisin parsinnoin" julkaistavaksi uudelleen suurempana painoksena. Pedagogisia muutoksia tekstiin teki varaesimies Ståhlberg, mutta varsinainen sisältö säilyi entisellään - siis varsin raamatullisena.

VSKS:n kustantaman alkeisoppikirjan nimeksi tuli Uusi Aapis-kirja, josta tilattiin Cederwallerin kirjapainolta huomattavan suuri 10 ooo kappaleen painos. Seura subventoi aapisen hinnan huomattavasti kilpailevia teoksia edullisemmaksi, ja tästä syystä sen menekki oli valtava: teosta julkaistiin vuosina 1847-1903 otetuissa 16 painoksessa yhteensä 144000 kappaletta. ${ }^{77}$

Ignatiuksen toisen, kirkollisten toimitusten käsikirjaa koskevan tarjouksen kirjallisuusseura sen sijaan hylkäsi. Perusteluissaan Ignatius oli kertonut joutuneensa "aina raskaalla mielellä lukemaan kirkollisia toimituksia virheellisistä käsikirjoista, joissa ei monessa paikoin [ollut] tointa tolkkuakaan". Seura ei voinut tukea sinänsä tarpeelliseksi katsottua hanketta, koska asiaa selvitettäessä kävi ilmi, että Porvoon tuomiokapituli oli jo asettanut komitean pohtimaan uuden käsikirjan julkaisemista. ${ }^{79}$

Tarpeellisemmaksi sen sijaan nähtiin maanviljelyskäsikirjan julkaiseminen, mutta siihen ei seuran piiristä löytynyt alaa riittävästi tuntevaa kirjoittajaa. Maatalouden edistämiseksi olikin - ja VSKS:n tavoin niin ikään Kanava-lehden kirjoituksen innoittamana - tekeillä oma seuransa, Viipurin läänin maanviljelysseura. Myös sen toimintaa viritteli 
alkuun K. H. J. Ignatius, jota ei kuitenkaan nimetty järjestön virallisiin toimielimiin. Maanviljelysseurasta muodostui kuvernööri von Kothenin johdolla säätyläismaanomistajien yhdistys, joka ei alkuvaiheessa ottanut aiotunlaista kansanvalistustehtävää. ${ }^{80}$

Ignatius toimi myös kirjastoliikkeessä, sillä hän oli perustamassa kaupunkiin kahta ruotsinkielistä lainakirjastoa (Wiborgs kontraktsbibliotek ja Svenska lånebibliotek). Kansalle tarkoitettujen pitäjänkirjastojen asiaa puolestaan edistivät tässä vaiheessa aktiivisesti Viipurilainen osakunta ja kirjallisuusseuran jäsen Johan Pynninen. ${ }^{81}$

Ignatiuksen toiminta koululaitoksessa oli sekin huomionarvoista, vaikka opetus tapahtui suureksi osaksi ruotsiksi. Jo 1830-luvun lopulla Ignatius opetti suomenmielisen C. W. Ahrenbergin yksityisessä koulussa yhdessä Uno Cygnaeuksen kanssa, joka myöhemmin mainitsi Ignatiuksen "kenties oivallisimmaksi ihmiseksi jonka oli oppinut tuntemaan". ${ }^{82}$ Kuolemansairaaksi keuhkotautipotilaaksi Ignatius osoitti koulutoimessa huomattavaa aktiivisuutta, sillä hän niin ikään perusti 1840-luvulla C. H. Ståhlbergin kanssa Viipuriin kaksi koulua: niin kutsutun Ståhlbergin kansakoulun rahvaalle sekä säätyläisille tarkoitetun lukioon johtavan yläalkeiskoulun, jonka rehtorina miehet vuorottelivat. ${ }^{83}$

Ignatiuksen opettajantyö kantoi hedelmää myös aatteellisesti. Kun kansanrunoustutkija ja suomalaisuusmies Julius Krohn muisteli myöhemmin asioita, jotka tekivät hänestä "Suomen miehen", hän mainitsi ensimmäisenä Viipurin lukion ilmapiirin. Lähtemättömän vaikutuksen häneen tekivät etenkin opettajien Ahrenberg, Ståhlberg ja Ignatius palava isänmaanrakkaus. ${ }^{84}$

Ignatiuksen merkittävin kouluteko ei silti liittynyt hänen omaan toimintaansa opettajana. Vieläkin kauaskantoisempaa näet oli, että hän esitti kevättalvella 1847 ystävälleen, liikemies Adam Wilkelle, ajatuksen varojen testamenttaamisesta VSKS:lle suomenkielisen, käytännön taitoja painottavan köyhän kansan koulun perustamiseksi Viipurin pitäjään tai Lappeen pitäjään. Tällaiselle koululle, jossa opetettaisiin kansalle hyödyllisiä tietoja ja maanviljelystä, Wilke neljä päivää ennen kuolemaansa testamenttasikin puolet varoistaan, noin 11000 ruplaa. ${ }^{85}$ Varat koulun perustamiseen tosin karttuivat riittäviksi vasta 186o-luvun alussa, jolloin Ignatius ei ollut enää todistamassa opinahjon avautumista.

Poliittisen ilmapiirin kiristyminen Euroopan vallankumousvuonna 1848 muutti VSKS:n toiminnan suuntaa monin tavoin, vaikka seuran pöytäkirjojen sivuilta käänne ei juurikaan heijastu. Seuraa johti jo vuodesta 1847 nimellisesti Viipurin hovioikeuden presidentti Carl Gustaf Mannerheim, jonka tiukan valvonnan alta moni VSKS:n ajamaksi tarkoitettu asia sanomalehden perustamisesta rahvaankoulujen pitämiseen vain liukui pois kirjallisuusseuran piiristä. Samojen hankkeiden toteuttamista seuran jäsenet jatkoivat yksityisinä 
aktiviteetteinaan. Keski-Euroopan tapahtumien myötä venäläiset vallanpitäjät alkoivat nähdä kumousvaaraa niin kansankoulutuksessa kuin kansankielisten uutistekstien levittämisessäkin. Viipurin sijainti Pietarin etumaastossa asetti vaarattomiltakin vaikuttaneet kansankoulutusaikeet riskialttiiseen valoon. Siihen hiipui fennomanian laajapohjainen suosio Viipurin säätyläispiireissäkin. ${ }^{86}$

Kuvernööri von Kothenin käskystä kirjallisuusseuralle laadittiin vuonna 1849 uudet säännöt, jotka muun ohella rajasivat ylioppilaat ja talonpojat pois jäsenistöstä. Näin jäsenmaksutulot ehtyivät huomattavasti. Sen sijaan keväällä 1850 annettu, suomenkielistä julkaisemista vaikeuttanut kieli- ja sensuuriasetus ei - toisin kuin esimerkiksi Teperi on katsonut - suoranaisesti pysäyttänyt seuran julkaisutoimintaa niin kauan kuin kyse oli taloudellista hyötyä tai uskonelämää palvelevista koulukirjoista. Käyntiin saatiin 1850-luvun alussa muun muassa geometrian ja maanviljelyksen oppikirjahankkeet. Vuonna 1851 seura alkoi lisäksi käännättää Friedrich Schödlerin viisiosaista teosta Naturens bok för skolan och hemmet. Kielisäännökset otettiin huomioon muokkaamalla alalukujen tavoitteeksi "hartauden herättäminen Jumalan luomistöiden äärellä". Sarjan ainoan valmiiksi tulleen osan, Physikin, käännöksen viimeisteli Ignatius itse. ${ }^{87}$

Huhtikuussa 1851 Ignatiuksen keuhkotauti paheni niin, että hän joutui luopumaan saarnaajan virasta työ- ja ojennuslaitoksessa. Hän haki vielä maaseudulle Kivennavan kappalaisen virkaan, mutta jäi toiselle ehdokassijalle. Opettajan työtään hän ei silti lopettanut. ${ }^{88}$ Myös kirjallisia töitään hän pystyi jatkamaan loppuun saakka. Eräät papit pyysivät keväällä 1855 kirjallisuusseuralta uutta bibliahistoriaa eli uskonnon alkeisoppikirjaa vedoten siihen, että vastaavat saatavilla olleet kirjat olivat köyhille liian kalliita. ${ }^{89}$ Tehtävä annettiin Ignatiukselle, joka käänsi ja toimitti sopivan bibliahistorian sairasvuoteellaan puolessa vuodessa. Toisin kuin muista seuran kustantamista teoksista, Ignatius sai tästä käännöstyöstä myös rahapalkkion. Rippi- ja rahvaankoulujen käyttöön aiottu Biblia-historia ilmestyi vain muutamia päiviä Ignatiuksen kuoleman jälkeen lokakuussa $1856 .{ }^{90}$

Seura sai Ignatiuksen kuolinvuonna valmiiksi useamman kirjahankkeen kuin koskaan aiemmin siihenastisen historiansa aikana. Silti uuden sukupolven edustaja, Wiborg-lehden päätoimittaja ja VSKS:n myöhempi esimies Carl Immanuel Qvist moitti seuraa vuonna 1857 passiivisuudesta ja luonnehti sen toimintaa olemattomaksi, sillä vuonna 1855 alkanut Aleksanteri II:n liberalismin aika oli nopeasti avannut mahdollisuuksia paljon monipuolisempaan työskentelyyn. Seuran uudistaminen alkoi sukupolvenvaihdoksen jälkeen. ${ }^{91}$ 


\section{IGNATIUKSEN JÄLKIMAINE}

K. H. J. Ignatius karttoi eläessään huomion kohdistumista omaan persoonaansa. Näkyvyyttä hän halusi pelkästään ajamilleen asioille: juopottelun vastustamiselle, suomenkielisen kansan koulutien tasoittamiselle ja kansankielisten valistustekstien levittämiselle. Hän oli omaksunut anonymiteetin ihanteen nähtävästi Martti Lutherilta. Lutherus-elämäkerrassaan Ignatius muistutti kohdehenkilönsä toivoneen oman nimensä painumista unohduksiin ja yksinomaan puhdistetun uskon jäämistä elämään: "Minä rukoilen, että jokainen antakoon minun nimeni olla mainitsemata, ja älköön sanoko itsenänsä Luteruslaiseksi, vaan Kristityksi. [- ] Mistä siis tapahtui minulle, wanhalle multasäkille, se kunnia, että Kristuksen lasta piti nimitettämän minun jumalattomalta nimeltäni!"92

Tämä piirre - henkilökohtaisen kunnian kaihtaminen - mainittiin myös muistokirjoituksissa, joita Ignatiuksesta julkaistiin viidessä suomen- ja ruotsinkielisessä sanomalehdessä; viipurilaisissa Wiborgissa ja Sanan-lennättimessä niitä julkaistiin useampiakin. Nekrologeissa nostettiin esille hänen luonteensa ja elämänsä vaatimattomuus, toimintansa pyyteettömyys sekä tunnontarkkuus työssä ja toimessa. Tunnollisuuden ajateltiin pakottaneen hänen jatkamaan saarnaajan työssä henkilökohtaisen terveyden kustannuksella liian pitkään, sillä tehtävään ei ollut löytynyt soveliaita jatkajia. Hänen papin ja opettajan kutsumustaan kuvattiin intohimoiseksi ja lämpimäksi, ja työn päämääräksi ihmiskunnan valaistuksen ja sivistyksen edistämistä. ${ }^{93}$ Arvonantoa osoitettiin hänen syvälle kutsumukselleen ja "muukalaisuudenkin" - toisin sanoen Viipurin monikielisten säätyläispiirien - keskellä säilyneelle isänmaanrakkaudelleen. Ignatiuksen tärkeimmiksi ansioiksi nousivat silti hänen työnsä suomenkielisenä valistuskirjailijana sekä toimeliaisuus VSKS:n perustamiseksi ja Wilken lahjoituksen järjestämiseksi. Hänen kerrottiin itse asiassa ahkeroineen "kaikkia sitte 1836 tähän kaupunkiin [Viipuriin] saatuja hyviä laitoksia". ${ }^{94}$

Snellman arvioi joulukuussa 1856 tekemässään kirjallisuuskatsauksessa, että jo manalle menneistä suomen kielen kirjallisen muodon vakiinnuttajista olisi "Suomen kirjallisuushistoria kiitollisena säilyttävä muiston herroista Judén, Renvall, Stråhlman, Collan, Keckman, Ignatius, Ticklén ja Nyman”. ${ }^{95}$ Nyt 160 vuotta myöhemmin näistä enää Judénin nimi tiedetään jollain tavoin historiapiirien ulkopuolella. Ignatiuksen elämäntyötä taas enää tuntee tuskin kukaan, mutta ei hän nimensä kuolemattomuutta tavoitellutkaan. Ignatiuksen toive Suomen kansan valistustason kohenemisesta ja koulutien avautumisesta sen sijaan toteutui vähitellen hänen kuolemansa jälkeisinä vuosikymmeninä. ${ }^{96}$

Ignatius vaikutti ratkaisevasti siihen, että Viipurin suomenkieliset maalaistulokkaat ja ruotsinkieliset säätyläiset yhdistivät voimansa ja alkoivat julkais- 


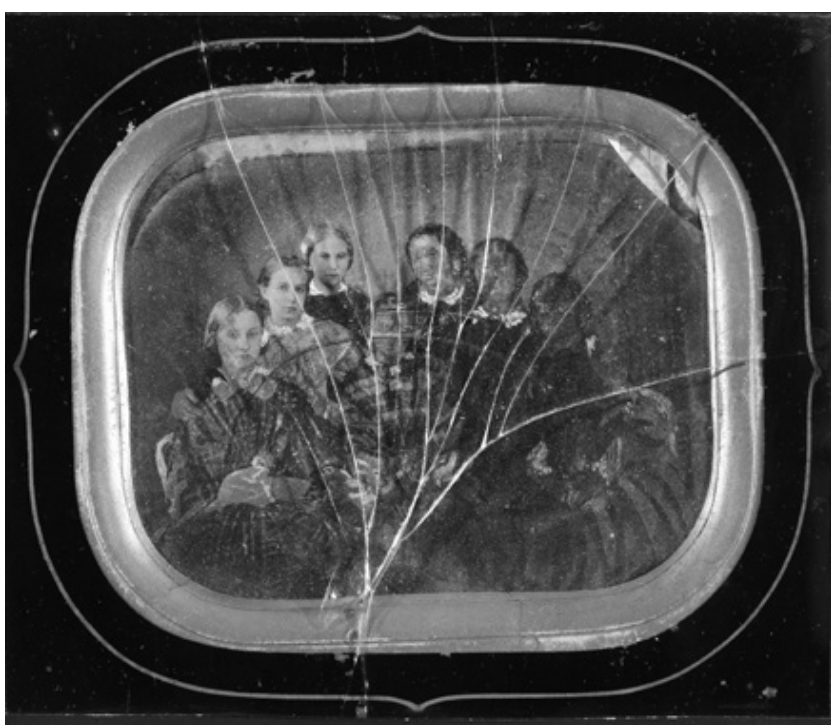

Viipurilaisen tyttökoulun oppilaita rikkoutuneessa ambrotyypissä vuodelta 1860. Keskellä Alexandrine von Rehekampf.

ta suomenkielistä oppi- ja valistuskirjallisuutta. Sama koskee kaikkea paikallista seuratoimintaa 180o-luvun puolivälin molemmin puolin. Hänen merkityksensä oli myös välillistä: Ignatiuksen ideoima testamenttilahjoitus toi Wilken koulun perustamisen jälkeen kaupunkiin opettajakuntaa, jonka panos kaupungin kulttuurielämään oli ratkaisevan tärkeä vuosisadan loppupuolella. Mainitsemisen arvoinen on hänen omakin vaikutuksensa tulevan sivistyneistön aatepohjaan etenkin lukion oppilaiden isänmaallisten tunteiden herättäjänä.

Ignatiuksen merkitystä lehtimiehenä ja oppi- ja valistuskirjallisuuden (myös käännöskirjallisuuden) edistäjänäkään ei pidä väheksyä. Hänen kirjailijantyönsä mittakaava ei ollut paikallinen, vaan esimerkiksi Aapiskirjan kirjoittajana osa suomenkielisen kansansivistyksen historiaa. Myös Luteruksesta ja Harjulan onnettomuudesta otettiin uusintapainoksia vielä Ignatiuksen kuoleman jälkeen ja ne kuluivat kansan käsissä eri puolilla Suomea. Ignatius vaikutti täysin ratkaisevasti siihen, että Viipurista tuli yksi varhaisen fennomanian keskuksista, vaikka yleisteoksissa päähuomio onkin kohdistunut snellmanilaiseen herätykseen ja sitä edeltäneeseen yliopistokaupunkien (ensin Turun ja 1820-luvun lopulta Helsingin) oppineen eliitin suomalaisuusliikehdintään.

Ignatiuksen merkitystä suomalaisuusliikehdinnän järjestäytymiselle ei ole missään nimessä väheksytty Viipurin kaupungin historiassa (1981), Teperin tutkimuksessa (1965) tai Aino-Maria Savolaisen Carl Henrik Ståhlbergia käsittelevässä tutkielmassa (2007). Sitäkin merkillisempää on, että hänen tarinansa puuttuu esimerkiksi Karjalaisesta elämäkerrastosta (1961) ja Kansallisbiografian henkilöartikkeleista. Toisaalta hänen nimensä jääminen unohduksiin kertoo ehkä enemmän Viipurin suomenkielisen kirjallisen elämän vilkkaudesta 1830-1840-luvuilla kuin Ignatiuksen työn vähäpätöisyydestä: historiankirjoituksessa hän jäi tuotteliaampien ja valovoimaisempien aikalaistensa Hannikaisen ja Juteinin varjoon.

154 | SUOMENKIELISEN KIRJALLISUUDEN KAUPUNKI 


\section{IGNATIUS, VSKS:N PROFIILI JA HISTORIANKIRJOITUS}

Vanhan Suomen suomalaisuusliikettä käsittelevässä tutkimuksessaan Jouko Teperi (1965) tulkitsi VSKS:n perustamisen osoitukseksi fennomanian järjestäytymisestä Viipurissa - aivan vastaavasti kuin SKS:n perustaminen vuonna 1831 oli ollut sitä Helsingissä. Liikehdinnän painopisteet eri kaupungeissa tosin poikkesivat toisistaan tässä artikkelissa aiemmin esitetyllä tavalla.

Teperi katsoi, että säätyjen välisten suhteiden kärjistyneisyys vei Viipurin läänissä kasvualustan runebergiläiseltä Helsingin romantiikalta, ja samasta syystä seudun kansallisesta liikehdinnästä muovautui ensisijaisesti valistuksellista. Käytännössä se tarkoitti, että kansankielellä nähtiin enemmän välinekuin itseisarvoa: parantamalla suomen kielen oikeuksia voitiin helpoimmin kohentaa myös rahvaan elinolosuhteita. Vastaavankaltaisen sosiaalisen fennomanian toinen pesäpaikka sijaitsi Viipurin ohella Kuopiossa, josta käsin maakunnassa syntyneet ylioppilaat levittivät valistusta Savon ja Pohjois-Karjalan takamaille. Sekä Kuopion että Viipurin sosiaalista fennomaniaa inspiroi erityisesti 1840-luvulla Snellmanin kansallinen herätystyö. Kansankoulutuksen ja -valistamisen päämääräkseen ottaneesta suomalaisuusliikehdinnästä on puhuttu itäisenä fennomaniana, jolloin se on asetettu vastakkain Helsingin yliopistopiirien vaaliman ruotsinkielisen kulttuurifennomanian kanssa. ${ }^{97}$

Tosiasiassa myös Viipurin lukion opettajien suomalaisuusharrastuksen tausta oli runebergilaisessa kulttuurifennomaniassa ja välillisesti jo Turun romantiikassa, ${ }^{98}$ vaikka osa heistä profiloitui kansanopetustyössään ja kirjallisuusseurassa toimiessaan ennen muuta valistuksellisiksi fennomaaneiksi. VSKS:n perustajiin kuuluneet Ståhlberg, C. W. Ahrenberg ja Ignatius saattoivat kansankynttilöinä olla myös kieleen välineellisesti suhtautuneita valistusmiehiä, mutta tulevan säätyläispolven opettajina he olivat ennen muuta isänmaata ja kansankieltä intohimoisesti rakastaneita romantikkoja.

Teperi katsoi herravihan ja paikallisten olojen arvostelun erottaneen viipurilaista fennomaniaa savokarjalaisesta. Viipurilaisen yhteiskuntakritiikin syyt hän näki aiheellisiksi ja monet epäkohdat - esimerkiksi pikkuvirkamiesten omavaltaisuudet - syvemmiksi kuin Savo-Karjalassa. Toisaalta VSKS:n ensimmäisen sukupolven luottamustoimien haltijat eivät olleet niinkään yhteiskuntakriitikkoja kuin rakentajia. He ohjasivat seuran alkuvuosien työskentelyn yksinomaan suomenkielisen julkaisutoiminnan ja muutaman runonkeruuretken tukemiseen. Tässä vaiheessa VSKS:n varoja käytettiin ensisijaisesti suomenkielisen rahvaan opintien tasoittamiseen julkaisemalla edullisia suomenkielisiä oppikirjoja. ${ }^{99}$ Tilanne olisi tosin voinut olla toisenlainen, mikäli seura olisi saanut luvan julkaista jo 1840-luvulla omaa sanomalehteä. ${ }^{100}$

Mikäli Ignatiuksen henkilöhistoriaa kuljettaa viipurilaisen fennomanian var- 
haishistorian johtolankana, vakiintunut käsitys Viipurin Suomalaisen Kirjallisuusseuran varhaisvaiheista ja tavoitteista saa uusia sävyjä, ellei jopa muutu kokonaan. VSKS:n alkuvuosien työmuotoja kehittivät käytännössä liberalismia kavahtaneet papit. ${ }^{101}$ Seuran ensi polven fennomania näyttäytyy lähinnä filantrooppisena ja jopa sosiaalikristillisenä kansanvalistusliikkeenä. Ignatius ja Ståhlberg kannattivat hengenmiehinä viime kädessä vanhojen yhteiskuntasuhteiden säilyttämistä; kumpikin heistä piti vastaavasti etäisyyttä myös epäilyttäväksi katsottuun herätyskristillisyyteen. Ignatiuksen tai Ståhlbergin kansanvalistustyö ei horjuttanut säätyrajoja: heidän laatimansa Aapiskirjan kasvatusihanteissa korostuivat ennen muuta nöyryys, jumalanpelko ja esivallan kunnioittaminen. Silti varsinkin Ignatius piti kansankielen huonoa asemaa vääryytenä ja aitona epäkohtana.

1840-luvun Viipurissa ärhäkkääksi yhteiskunnan arvostelijaksi profiloitui Snellmanin innostamana lähinnä Pietari Hannikainen Kanava-lehdessään. Hannikaisen yhteydet VSKS:aan taas jäivät varsin ohuiksi ja lähes katkesivat erään velkakiistan takia vuonna $1848{ }^{102}$ Hannikaisen kaltaisten yksittäisten radikaalien maine leimasi koko suomalaisuusliikehdinnän varhaisvaiheen uudistusmielisemmäksi kuin se olikaan. Toisaalta sekä Hannikaisen liberaalin lehtimiestyön että pappisfennomaanien kristillisen filantropian päämäärät olivat yhteiset: molemmat pyrkivät toimimaan suomenkielisen kansan tietämyksen ja elinolojen parantamiseksi. Pelkästään erimielisyydet keinoista eivät riittäneet ajamaan niitä avoimeen välirikkoon.

Paikallisten fennomaanien sisäiset linjaerot eivät nousseet historiankirjoituksen kohdevaloihin, koska 1840-1850-luvun Viipurin kulttuurielämä tarjosi historiapoliittisesti käyttökelpoisemman narratiivin aineksia. Niitä muodosti erityisen kiinnostavaksi koettu jännite 1850-luvun taitteen fennomaanien tai liberaalien sekä keisarille lojaalien byrokraattien - ja heidän takanaan koko Venäjän keisarikunnan - välillä.

Viipurin kielioloja, kulttuuria ja poliittista elämää käsitelleiden tutkimusten tulkintoihin ovat lyöneet leimansa niin vuosisadan vaihteen kaksi sortokautta kuin kaupungin luovutus Neuvostoliitolle talvi- ja jatkosodan jälkeen. Ignatius jäi sivuun jo kansallisten suurmieskulttien rakennusvaiheesta: hänen tarinassaan ei ollut aineksia sankaruuteen, sillä hän ei ollut kirjoittajana kansasta noussut nero eikä hengenmiehenäkään vastarintaa edustanut herätyspappi. Lyhyeksi jäänyt elämä jätti kaunokirjallisen tuotannonkin niukanlaiseksi; sisältö oli yksioikoista eikä erityisen omaperäistä, vaikka kieli kiitosta saikin. Seuran puitteissa syntyneet oppikirjat hän taas julkaisi anonyymina.

Toisen maailmansodan jälkeisinä vuosikymmeninä Viipurin historiasta kirjoitti lähinnä paikallinen siirtoväki, jonka tulkinnoissa Viipurin kulttuurin 
sinänsä kiistaton omaleimaisuus korostui jopa tendenssiksi asti. Toisaalta 1960-1970-luvun oloissa ehkä koettiin tarkoituksenmukaiseksi häivyttää viipurilaisen suomalaisuusliikehdinnän romanttisia elementtejä - siinä kuin toisaalta 180o-luvun puolivälin Viipurissa yleistä keisarilojalismiakin. Liberaalien lehtimiesten sosiaaliradikalismi tarjosi tuolloiselle lukijalle samaistumisen kohteen poliittisesta suuntautumisesta riippumatta: se voitiin asemoida yhtä lailla vasemmistolaisuuden esihistoriaan kuin osoitukseksi suomalaisten kansallisesta vastarinnasta venäläistä vallanpitäjää kohtaan. Tällaisessa ilmapiirissä Ignatiuksen kaltaiset kristilliset konservatiivit ja raittiuskirjailijat eivät nähtävästi nousseet kiinnostaviksi tutkimuskohteiksi.

\section{Viitteet}

1 Artikkeli on kirjoitettu Koneen Säätiön K. H. J. Ignatiuksen elämäkerralliseen tutkimukseen myöntämällä rahoituksella.

2 Teperi 1965, 41-73; Kaukiainen 2014, 12-13; Koskivirta 2014a, 378-398.

3 Suomen historian yleisesityksistä Arvi Korhosen toimittama Suomen historian käsikirja (1949) ja Jouko Vahtolan Suomen historia jääkaudesta Euroopan unioniin (2003) eivät käsittele viipurilaisia kirjailijoita tai paikallista suomalaisuustoimintaa. Karjalankin historiaa tuotannossaan käsitellyt Pentti Virrankoski mainitsee Suomen historiassaan (2009) Juteinin ja Hannikaisen molemmat kerran, niin kuin Aleksis Kivenkin. Einar W. Juveliuksen Suomen kansan aikakirjoissa (osa 7, 1951) Juteinille on omistettu 30-sivuinen artikkeli ja Mikko Juvan Suomen kansan historiakin (1961) muistaa Juteinin, jonka, samoin kuin VSKS:nkin mainitsee ohimennen myös Helge Pohjolan-Pirhonen yleisesityksessään Kansakunnan historia (osa 3, Kansakunta löytää itsensä 1809-1855, 1973). Asiantuntijoiden laatimassa yleistajuisessa Oma maa -sarjassa (1907-1962) Juteinia käsiteltiin 11 sivun ja Hannikaista 7 sivun verran. Suomen historian yleisesityksissä Juteini nouseekin laajan yhteiskunnal- lisen merkityksensä takia jopa Aleksis Kiveä keskeisemmäksi hahmoksi, kun voimasuhteet kirjallisuushistorioissa ovat selvin numeroin päinvastaiset. Vrt. Pentti Paavolaisen kirjallisuusartikkeli tässä kokoelmassa, s. 128, viitteet 21 ja 25. Suomen kulttuurihistorian yleisesityksissä Viipurin suomalaisuusliikehdintää käsitellään melko tiiviisti. Suomen kulttuurihistoria (osa 3, 1935) mainitsee Juteinin, muttei käsittele viipurilaista kieliliikehdintää muulla tavoin. Päiviö Tommilan toimittamassa Suomen kulttuurihistoriassa, osa 2, WSOY 1980) VSKS: n toimintaa ja Vanhan Suomen kulttuuria laajemminkin käsittelee Matti Klinge, lisäksi Hannikaista käsitellään lyhyesti sekä näytelmäkirjallisuutta että sanomalehdistöä koskevissa osuuksissa. Myös Juteinista kirjoitetaan noin 10 rivin verran ensisijaisesti valistuskirjailijan yhteiskunnallisen merkityksen näkökulmasta. Laura Kolben toimittama Suomen kulttuurihistoria (osa 2, Tammi 2002) mainitsee Hannikaisen Silmänkääntäjän ja sanomalehti Kanavan. Juteini mainitaan neljästi, ja kirjallisuusseuraa käsitellään erityisesti kirjastolaitoksen yhteydessä. Sekä Tommilan että Kolben toimittamat kulttuurihistoriat antavat huomiota myös viipurilaisen Johan Pyn- 
nisen merkitykselle kansankirjastoliikkeen käynnistäjänä.

4 Lahjoitusmaakysymystä ei mainitse suomalaisuustoiminnan taustalla esimerkiksi K. Krohn 1917. Sitä vastoin Teperi 1965, 74-90; toisaalta Kaukiainen 2014b, 13-20, 36-37; myös Koskivirta 2014c, 378-397. Lahjoitusmaatalonpoikien asemasta yleisemmin: Paaskoski 2013.

5 Tarkemmin: Koskivirta 2014d.

6 Ignatiuksesta on laadittu wikipedia-artikkeli, mutta ei esimerkiksi henkilöartikkelia Kansallisbiografiaan. Hänestä on lyhyt artikkeli Biografisessa nimikirjassa (1883), muttei esimerkiksi Jaakko Paavolaisen 1961 toimittamissa Karjalaisessa elämäkerrastossa.

7 Elämänkertatiedot on koottu muistokirjoituksista ja matrikkelitiedoista, esim. Kotivuori 2005 (http://www. helsinki.fi/ylioppilasmatrikkeli/henkilo. php?id=14576, luettu 22.1.2016); Lundén Cronström \& Hornborg 1961; "Viipurista. Kuolon-sanoma”. Sanan-lennätin 18.10.1857.

8 Laasonen 2012; Lundén Cronström \& Hornborg 1961.

9 Sanan Saattaja Wiipurista 22.2.1840; vrt. myös J. Krohn 1897 (ei sivunumeroa).

10 Sanan Saattaja Wiipurista 4.7.1840; Sala 2008; vrt. esim. Heininen 2012b, 72-77; Riikonen 2012, 40-50.

11 Kotivuori 2005 (http://www.helsinki.fi/ylioppilasmatrikkeli/henkilo. php?id=14576, luettu 22.1.2016); Nygård 1985, 119-128; Koskivirta 2014c, 98-100.

12 Vrt. Marttinen 2006, 15-20.

13 Jaakko Jaakonpoika. 1840. Tarpeellinen Lasten-kirja. Helsinki: Frenckell \& poika; SKS: virka-arkisto, kirjeenvaihto, saapuneet kirjeet. K.H.J. Ignatius SKS:Ile 14.12.1839; Sulkunen 2004, 172.

14 Huoneentaulun ajasta ja kasvatusihanteista: Hanska \& Vainio-Korhonen 2010.

15 Vrt. Teperi 1972; Juteinin teoksen suosiota osoittavat siitä otetut kolme painosta: Juteini, Jak. (1816, 1819, 1826) Lasten kirja: koetus. Viipuri: Cederwaller.
16 Teperi 1965, 47-49; Kähäri 1981, 608; Tommila 1988, 127-128; Stadius 2002, 72-78.

17 Sanan Saattaja Viipurista 4.1.1840.

18 Vrt. Laasonen 2001.

19 Ignatiuksen toimittamat lehdet kootusti: Kotus, varhaisnykysuomen korpus,

Sanan Saattaja Viipurista, vuosikerrat 1840, 1841 (http://kaino.kotus.fi/korpus/1800/meta/ssv/ssv_coll_rdf.xml); KK, Historiallinen sanomalehtikirjasto (http://digi.kansalliskirjasto.fi/sanomalehti/titles/1457-4586/1840).

20 Kuismin 2012, 85; Alhoniemi 1969, 79, 44.

21 Runo kokonaisuudessaan: Sanan Saattaja Viipurista 4.7.1840; myös TalviOja 1915, viite 60.

22 Sanan Saattaja Viipurista, 22.2.1840; Paavolainen tässä kokoelmassa, 103-105.

23 Koskivirta 2014c, 72-74.

24 "Vaarin otettavia”. Sanan Saattaja Viipurista 2.5.1840.

25 "Juttu-uhri". Sanan Saattaja Viipurista 14.3 .1840

26 Vrt. Koskivirta 2014c, 74-77; Kaukiainen 2014b, 31-33.

27 Stadius 2002, 72-74; Teperi 1965, 47, 51. Epäkohdista ja Viipurin fennomaanien oikeudellisen suuntautumisen taustoista Koskivirta 2014b; Tommila 1988, 127.

28 SKS: Kirjallisuusarkisto, Elias Lönnrotin kirjeet 1840-1848, saapuneet kirjeet 5 397-400, 433-426; 6: 363-366. Ignatius Lönnrotille 8.9.1841; 13.10 .1841 ja s.d.

29 Sanan Saattaja Viipurista, 28.12.1841.

30 Kotivuori 2005 (http://www.helsinki.fi/ylioppilasmatrikkeli/henkilo. php?id=14576, luettu 22.1.2016).

31 Teperi 1965, 23-32; K. Krohn 1917.

32 Kielioloista: esim. kokoelman Tandefelt 2002a artikkelit; A.-M. Savolainen 2007, 20-29; Einonen 2013b; Kaukiainen 2013, 75-87; Paavolainen tässä kokoelmassa, 99-100, 106. Säätyläisnaisten suomen kielen taidosta: Åkerman, D. W. 1914. Muistelmia. Piirtänyt D. W. Åkerman. Aloitettu 4.17.1913. Käsikirjoitus Voipion suvun hallussa. 
33 Ignatiuksen sairastelu lisäsi Ståhlbergin työtaakkaa lukiolla: Ståhlberg Lönnrotille 19.2.1845, Soiniola 2005, 55.

34 HiSKi-tietokanta, Viipurin ruotsalainen srk, kastettujen luettelo, hakusana "Ignatius"; KA: kirkonarkistot, Arkiv av Viborgs stads svenska församling, syntyneiden ja kastettujen luettelot, 1843, 1845, 1847, 1849; vrt. A.-M. Savolainen 2007, 44-45.

35 Gossner, Johannes (1843). Jesus ihmisen sydäntä kolkuttava, suomentanut Jaakko Jaakonpoika. Porvoo; Franklin Benjamin (1842). Neuwoja kaikille säädyille rikkaaksi ja onnelliseksi päästäksensä, Benjami Franklinin mukaan; suomentanut Jaakko Jaakonpoika. A. C. Öhman: Porvoo (2. painos Edlund, Porvoo); Paloposki 2008, 3.

36 Sulkunen 2004, 86-90.

37 Aikeesta uutisoi "Inrikes", Helsingfors tidningar 8.2.1845. Saman lehden kirjallisuuskatsauksessa "Vår literatur", 28.6.1845 sarjan ensimmäistä osaa suositeltiin kansan lukemistoksi monille läheisen aiheen takia.

38 Saima 23.10.1845, käännös (http://snellman.kootutteokset.fi/fi/dokumentit/saima-nro-43-23101845, luettu 21.1.2016)

39 Ignatius, Karl Henrik Jakob. 1845. Harjulan onnettomuus. Lukemisia Suomen kansalle. Helsinki: Frenckell; Ståhlberg Lönnrotille 19.2.1845, Soiniola 2005, 55.

40 "Inhemsk litteratur", Morgonbladet 37, 22.5.1845; Vrt. myös esim. Henrik Renqvistin Viinan kauhistus (1835); Kirjan kieltä kehuttiin jopa lähes Lönnrotin veroiseksi: Maamiehen ystävä 26.4.1845. Suomi-lehti (4.12.1847) tosin piti Ignatiuksen lauserakenteita liian monipolvisina talonpoikaisille lukijoille. Toisaalta kirjoittaja luonnehti Ignatiuksen tyyliä "jykeäksi haastiksi" vastakohtana muiden suomenkielisten kaunokirjailijoiden "kepeälle tai herkälle haastille".

41 Teperi 1965, 93. Valistavasta kansankirjallisuudesta: vrt. myös Moilanen 2008, 40-42. SKS:n julkaisutoiminnasta 1830-1850-luvulla toisaalta: Sulkunen
2004, 104, 302. SKS julkaisi 1840-luvulla suomeksi myös esimerkiksi historian ja geometrian oppikirjoja. Näissä aineissa VSKS ei puolestaan tehnyt oppikirjoja.

42 Kirjojen levinneisyys Suomessa vuoteen 1850, tietokanta (http://avaa.tdata.fi/ web/kirjahistoria/kirjakartoitus, hakusana "Ignatius, Karl Henrik Jakob", luettu 30.1.2016).

43 SKS: kirjallisuusarkisto, SKS:n virka-arkisto, kirjeenvaihto 1839-1849, saapuneet kirjeet. Erik Gabriel Melartin SKS:Ile 21.5.1845

44 Ignatius, Karl Henrik Jakob. 1845. Martti Luterus. Lukemisia Suomen kansalle. Helsinki. Joidenkin tietojen (viite 42) mukaan teos mukaelma saksankielisestä alkuperäisteoksesta, mutta aikanaan se on katsottu Ignatiuksen omaksi tuotannoksi.

45 Esim. Saima 5.9.1846 (käännös, http:// snellman.kootutteokset.fi/fi/dokumentit/kallavesi-nro-3-saiman-liite-591846, luettu 21.1.2016).

46 "Om filial-föreningar för Finska Litteratursällskapet”, Saima 17.4.1845.

47 "Suomen kirjallisuuden Seuran apuyhteyksistä”, Kanava 17.5.1845.

48 Heitä olivat esimerkiksi C. H. Ståhlberg ja Wolmar Schildt. SKS: Kirjallisuusarkisto, virka-arkisto, Kirjeenvaihto 1839-1849, Ståhlberg SKS:Ile 2.1.1846; Schildt SKS:Ile 5.12.1846. Schildtin aloitteesta vuonna 1865 perustettiin Jyväskylän Suomalaisen Kirjallisuuden seura, mutta sen toiminta jäi vähäiseksi, koska SKS sanoutui irti Schildtin ajamasta venykekirjoitusjärjestelmästä. Seura lakkautettiin vuonna 1911. KA: Jyväskylän Suomalaisen Kirjallisuuden Seuran arkisto, kuvailutiedot.

49 Muistokirjoitukset: Teperi 1967; Kähäri 1981.

50 Teperi 1965, 197-210.

51 Sanan Saattaja Viipurista, 4.1.1833.

52 A.-M. Savolainen 2007, 30-39.

53 Esim. Teperi 1972.

54 Esim. Heininen 2012b, 72-79.

55 Esim. A.-M. Savolainen 2007, 21; Teperi 1972; Sulkunen 2004, 68-74. 
56 "Om filial-föreningar för Finska Litteratursällskapet”, Morgonbladet 9.6.1845; Sulkunen 2004, 88-90.

57 "Om filial-föreningar för Finska Litteratursällskapet”, Morgonbladet 9.6.1845.

58 Tarkemmin: Paavolainen tässä kokoelmassa, 106-113.

59 Ignatiuksen ja Hannikaisen kirjallista suhdetta kuvaa myös Paavolaisen tässä kokoelmassa mainitsema tapaus, 129, viite 36

60 Teperi 1965, 67; Kyyrö 1966. Seuran säännöistä: Paavolainen tässä kokoelmassa, 106.

61 Teperi 1965, 93; Sulkunen 2004.

62 Teperi 1965, 26-27, 41-90.

63 KA: VSKS:n arkisto, pöytäkirjat ja toimintakertomukset 1845-1856; Teperi 1965, 74-136; Sulkunen 2004, 94.

64 KA: VSKS: $n$ arkisto, Toimintakertomus, ensimmäinen vuosi (1846).

65 Joskus tuntemattomaksi allekirjoittajaksi uskottu, järjestyksessä kuudes nimi on tosiasiassa Adam Paunosen allekirjoituksen alle merkitty titteli Heretz Duomor (herastuomari).

66 KA: kirkonarkistot, Arkiv av Viborgs stads svenska församling, syntyneiden ja kastettujen luettelot 1843, 1845, 1847, 1849.

67 Teperi 1965, 54-73.

68 Koskivirta 2014b, 380-390.

69 Teperi 1965, 73, 94.

70 KA: VSKS:n arkisto, Toimintakertomukset 1846, 1847.

71 KA: VSKS:n arkisto, Toimintakertomus, ensimmäinen vuosi (1846).

72 K. Krohn 1917, 51.

73 Klinge 1975, 65; Sulkunen 2004, 95; myös Teperi 1965, 94.

74 Näistä tunnetuin on SKS:n kanssa lähes yhtä aikaa julkistettu palkintokilpailu suomen kielen kieliopin kirjoittamiseksi. SKS: virka-arkisto, kirjeenvaihto, Bergbom ja Ståhlberg (käsialan perusteella tosiasiallisesti Ignatius) SKS:Ile 7.6.1846; 3.10.1846; 30.10.1846; Sulkunen 2004, 91-95.

75 KA: VSKS:n arkisto, Toimintakertomukset 1846, 1847, 1848; seuran ja lohkokuntien pöytäkirjat 1846-1848; SKS: virka-arkisto, kirjeenvaihto, Ståhlberg et al. SKS:Ile. 6.4.1847; Ignatius ja Ståhlberg SKS:Ile 4.5.1847; Ignatius SKS:IIe 15.2.1848. Ståhlberg Lönnrotille 25.5.1847, Soiniola 2005, 63.

76 KA: VSKS:n arkisto, pöytäkirjat 18451846; toimintakertomus 1850.

77 Teperi 1965, 116; Kyyrö 1966; Sulkunen 2004. Tosin Teperin tiedon mukaan teosta painatettiin kaikkiaan 450000 kappaletta.

78 Teperi 1965, 116; Sulkunen 2004, 94.

79 KA: VSKS:n arkisto, pöytäkirja 1846; pöytäkirja 3.2.1847, 7-8; lohkokunnan pöytäkirjat 17.2.1847, 2; 6.4 .1847 (ainoa käsitelty asia). Ignatius oli puhunut asiasta myös vuosikokouksessa.

80 "Nekrolog", Wiborg 17.10.1856; Puhakka 1910.

81 "Nekrolog", Wiborg 17.10.1856; myös Henriksson 1961; Mäkinen tässä kokoelmassa, 81.

82 Tosin ystävyys sai särön, kun Cygnaeus ei kertonut Ignatiukselle avioliitostaan eikä kutsunut tätä häihinsä. KK: käsikirjoituskokoelmat: SLS, Historiska och litteraturhistoriska arkivet, Brev till Karl Henrik Ignatius. SLSA 177; Teperi 1965, 29.

83 Savolainen 2007, 50, 74.

84 J. Krohn 1897

85 Testamentissa muistettiin myös Wilken kummipoikaa, tuolloin sylilapsi-ikäistä Robert Ignatiusta, joka oli K.H.J. Ignatiuksen poika. KA: VSKS:n arkisto, Adam Wilken testamentti.

86 Esim. Teperi 1965, 137-161; A.-M. Savolainen 2007, 45-46.

87 KA: VSKS:n arkisto, pöytäkirjat ja toimintakertomukset 1850-1852; Nurmio 1947, 129-143; 138, 150-153, 163-166.

88 Borgå Tidning 15.12.1852.

89 KA: VSKS:n arkisto, Pöytäkirja 4 §, 2.4.1855.

90 KA: VSKS:n arkisto, Toimintakertomus 1856.

91 "Suomalaisen Kirjallisuuden Seuran (12:s) vuosikertomus 3. helmikuuta 1857", Sanan-lennätin 7.2.1857; Wiborg 
21.8.1957; A.-M. Savolainen 2007, 49-52; Teperi 1965, 162-178.

92 Ignatius, Karl Henrik Jakob (1845), Martti Luterus. Lukemisia Suomen kansalle. Helsinki, 157.

93 VSKS:n varaesimiehen Q. I. Qvistin päätoimittaman Wiborg-lehden mukaan VSKS nimeää Ignatiuksen seuran varsinaiseksi perustajaksi (egentliga stiftare) "Nekrolog", Wiborg 17.10.1856; "Landsorterna”, Åbo underrättelser 24.10.1856; "Runoja, luetuita Karl Henrik Jakob Ignatiuksen haudalla", Sanan-lennätin 25.10.1856; "Kuolon sanoma", Suometar 24.10.1856; Helsingfors Tidningar 22.10 .1856

94 "Vaikka hän vietti pisimmän ja paraan elinaikansa muukalaisuuden keskellä, säilyi hänen sydämensä kuitenki aina suomalaisena loppuunsa saakka”. Suomalaisen Kirjallisuuden Seuran 12:s vuosikertomus, Sanan-lennätin 7.2.1857; Viipurista. "Kuolon-sanoma", Sanan-lennätin 18.10 .1856$.
95 Litteraturblad 1.12.1856.

96 Tarkemmin: Koskivirta 2014b, 390-398.

97 Teperi 1965, 91-111.

98 Sieltä inspiraationsa oli saanut koulun rehtorinakin 1830-luvun alkuvuosina toiminut A. J. Europaeus ja VSKS:n ensimmäinen esimies J. E. Bergbom. P. Paavolainen 2014, 29-30.

99 Poikkeus oppikirjalinjasta on VSKS:n esimies Mannerheimin suututtanut Antti Rädyn laulukirja, jonka seura julkaisi vuonna 1849. Seura olisi julkaissut myös D. E. D. Europaeuksen runoteoksen Tähtivyö, mikäli kirjoittaja olisi tehnyt siihen kommentaatorien toivomat muokkaukset: Lönnrot Ståhlbergille 19.3.1847, Soiniola 2005, 61.; Teperi 1965, 141, 143, 160.

100 Sen estymisestä: Paavolainen tässä kokoelmassa, 110-113.

101 Ståhlberg suoritti pastoraalitutkinnon 1847. Esim. A.-M. Savolainen 2007, 73.

102 KA: VSKS:n arkisto, pöytäkirjat 1847-1848. 